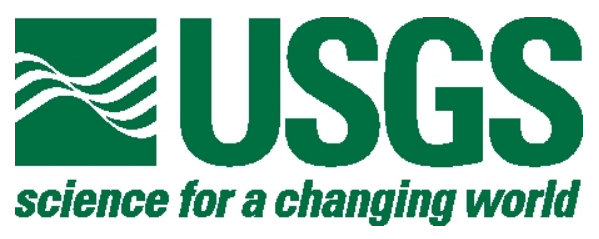

\title{
Facies Analysis of Tertiary Basin-Filling Rocks of the Death Valley Regional Ground-Water System and Surrounding Areas, Nevada and California
}

By Donald S. Sweetkind, Christopher J. Fridrich, and Emily Taylor

Open-File Report 01-400

Prepared in cooperation with OFFICE OF ENVIRONMENTAL RESTORATION AND WASTE MANAGEMENT, U.S. DEPARTMENT OF ENERGY

NATIONAL NUCLEAR SECURITY ADMINISTRATION

NEVADA OPERATIONS OFFICE, under

Interagency Agreement DE-AIO8-96NV11967

2001

This report is preliminary and has not been reviewed for conformity with U.S. Geological Survey editorial standards or with the North American Stratigraphic Code. Any use of trade, product, or firm names is for descriptive purposes only and does not imply endorsement by the U.S. Government.

U.S. DEPARTMENT OF THE INTERIOR

U.S. GEOLOGICAL SURVEY 


\section{Contents}

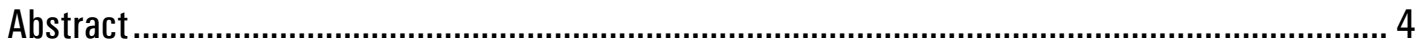

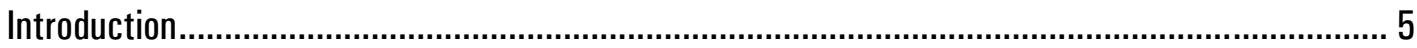

Cenozoic Stratigraphy of the Death Valley Region ...................................................................... 7

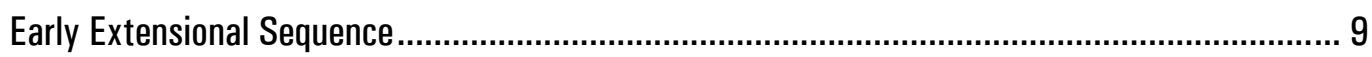

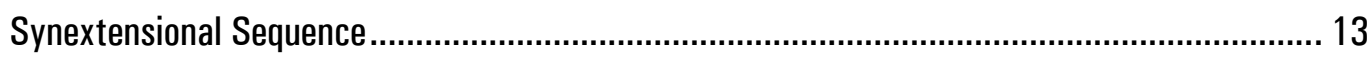

Late extensional/post-extensional sequence ……………………………………………... 18

Stratigraphic Setting of Tertiary Basin-Filling Deposits ............................................................ 18

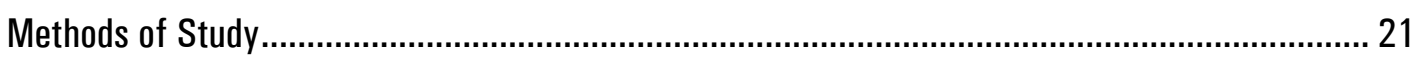

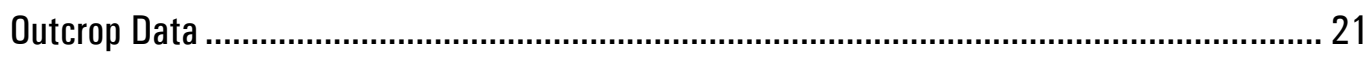

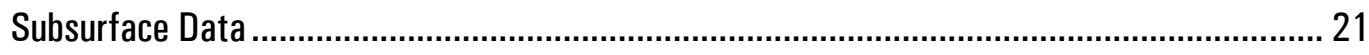

Tertiary Thickness Modeled from Gravity Data ............................................................... 32

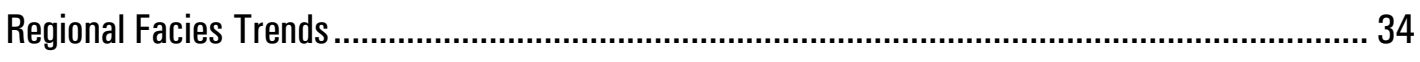

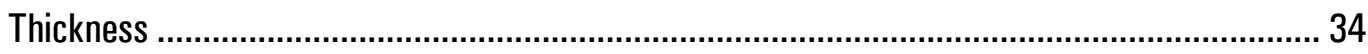

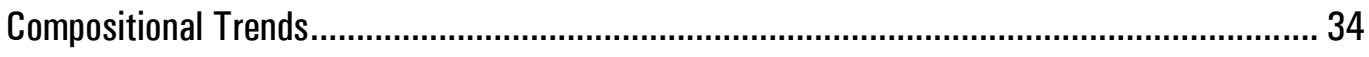

Amargosa Desert Borehole Data .................................................................................. 41

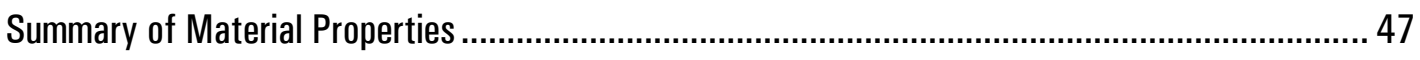

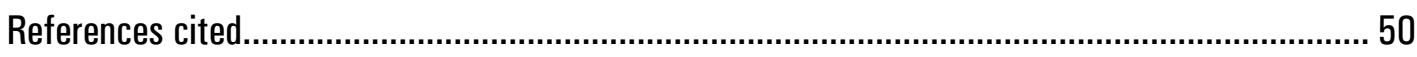

\section{Figures}

1. Location map and place names, Death Valley region ......................................................... 6

2. Diagrammatic examples of possible stratigraphic position of undifferentiated

Tertiary volcanic and sedimentary rocks .................................................................... 20

3. Location map of outcrops and boreholes used in this study ……........................................ 22

4. Thickness of Cenozoic basin fill based on gravity model ..................................................... 33 
5. Thickness of undifferentiated Tertiary basin fill based on measurements in

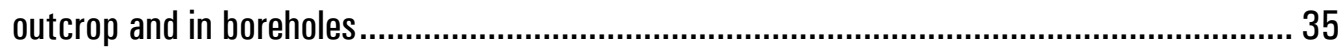

6. Thickness of Tertiary sedimentary rocks based on measurements at outcrops and in boreholes

7. Thickness of Tertiary volcanic rocks outside the southwestern Nevada volcanic field

8. Thickness of Tertiary limestones based on measurements at outcrops and in boreholes

9. Relative proportion of sedimentary rocks in the Tertiary section and grain-size characteristics. 40

10. Relative proportion of volcanic rocks in the Tertiary section and rock type 42

11. Location map of boreholes and stratigraphic cross sections in the vicinity of the Amargosa Desert.

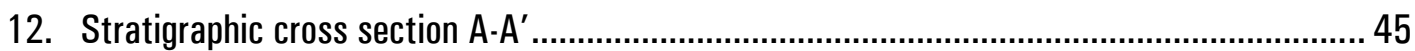

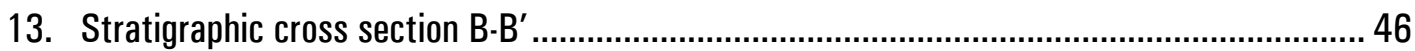

14. Map showing location of zones that may define major regional differences in material properties

\section{Tables}

1. Location of outcrop data used for facies analysis

2. Thickness data for lithologic types from measured sections and outcrop descriptions

3. Location of borehole data used for facies analysis.

4. Thickness data for lithologic types from boreholes 


\title{
Facies Analysis of Tertiary Basin-Filling Rocks of the Death Valley Regional Ground-Water System and Surrounding Areas, Nevada and California
}

By Donald S. Sweetkind, Christopher J. Fridrich, and Emily Taylor

\begin{abstract}
Existing hydrologic models of the Death Valley region typically have defined the Cenozoic basins as those areas that are covered by recent surficial deposits, and have treated the basin-fill deposits that are concealed under alluvium as a single unit with uniform hydrologic properties throughout the region, and with depth. Although this latter generalization was known to be flawed, it evidently was made because available geologic syntheses did not provide the basis for a more detailed characterization. As an initial attempt to address this problem, this report presents a compilation and synthesis of existing and new surface and subsurface data on the lithologic variations between and within the Cenozoic basin fills of this region. The most permeable lithologies in the Cenozoic basin fills are freshwater limestones, unaltered densely welded tuffs, and littleconsolidated coarse alluvium. The least permeable lithologies are playa claystones, altered nonwelded tuffs, and tuffaceous and clay-matrix sediments of several types. In all but the youngest of the basin fills, permeability probably decreases strongly with depth owing to a typically increasing abundance of volcanic ash or clay in the matrices of the clastic sediments with increasing age (and therefore with increasing depth in general), and to increasing consolidation and alteration (both hydrothermal and diagenetic) with increasing depth and age. This report concludes with a categorization of the Cenozoic basins of the Death Valley region according to the predominant lithologies in the different basin fills and presents qualitative constraints on the hydrologic properties of these major lithologic categories.
\end{abstract}




\section{Introduction}

Cenozoic basin-fills of the Death Valley region (fig. 1) range from late Eocene to Quaternary in age, from coarse to fine in grain size, from fresh to strongly altered, and from unconsolidated to well consolidated. They include a broad range of both volcanic and sedimentary lithologies including lavas, welded and nonwelded tuffs, and alluvial, fluvial, colluvial, eolian, paludal, and lacustrine sediments. The presence of excellent aquifers within parts of these basin fills has been demonstrated by long-term well-water production (Dudley and Larson, 1976; Harrill, 1986), whereas the presence of spring discharge sites in other areas has been related to structural juxtaposition of confining units within some basin fills against more permeable rocks (Winograd and Thordarson, 1975; Hunt and others, 1966; Dudley and Larson, 1976). Despite their great lithologic diversity and proven large variation in hydrologic behavior, those parts of the Cenozoic basin-filling sequences of the Death Valley region that are covered by recent surficial deposits have commonly been modeled as a unit with uniform hydrologic properties, both throughout the region and with depth (IT Corp., 1996; D'Agnese and others, 1997).

Much of the mystery surrounding the Cenozoic basin fills of the Death Valley region reflects the fact that the basins typically have been defined in hydrologic models as the areas of present-day cover by unconsolidated surficial deposits. These recent surficial deposits are also part of the Cenozoic basin fills, but in most of the region are too thin to extend below the water table. Lateral lithologic variations in these largely post-tectonic surficial deposits typically bear little or no relationship to those in the older, dominantly synextensional and early extensional basin-fill deposits at the depth of the water table and below. Exposures of consolidated Cenozoic strata are treated in most hydrologic models as a separate hydrologic unit (or units) from adjacent, concealed basin-fill strata. However, most outcrops of consolidated Tertiary strata that are exposed adjacent to alluvial cover are within the original area of the basins, most of which formed in the Miocene. In most cases, these strata project down under the adjacent alluvium and are the lateral equivalents to strata concealed under the recent alluvium. These exposures of basin fill show that strong lateral changes in lithology, thickness, and structure exist 


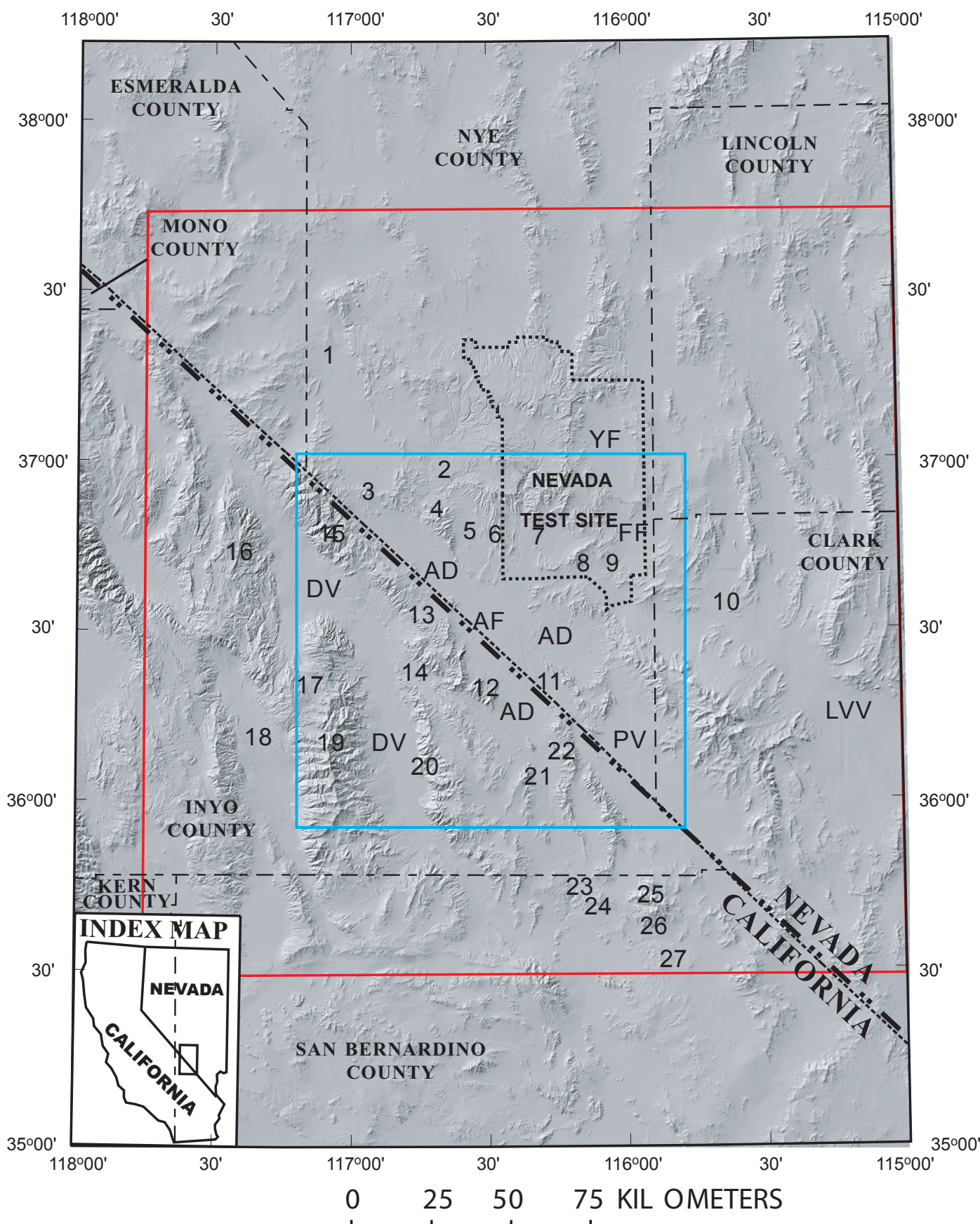

\section{EXPLANATION}

Line of section

- - State boundary

- - - County boundary Nevada T est Site boundary

Area depicted on figures 3-10

Area depicted on figure 11

$A D=$ Amargosa Deser $t$ $\mathrm{AF}=$ Amargosa $\mathrm{F}$ arms area $\mathrm{DV}=$ Death $\mathrm{V}$ alley

$\mathrm{FF}=\mathrm{F}$ renchman Flat

$\mathrm{LVV}=\mathrm{L}$ as Vegas Valley

$\mathrm{PV}=\mathrm{P}$ ahrump Valley

$\mathrm{YF}=\mathrm{Y}$ ucca Flat

$1=$ Sar cobatus Flat

2 = Oasis V alley basin

$3=$ Bullfrog Hills

$4=$ Bar e Mountain

$5=$ Crater Flat

$6=Y$ ucca Mountain

$7=$ Jackass Flat

$8=$ Rock $V$ alley

$9=$ Hampel W ash

$10=$ Indian Springs

$11=$ Ash Meadows

12 = Bat Mountain

$13=\mathrm{F}$ uneral Mountains

$14=$ F urnace Creek Wash

$15=$ Grapevine Mountains $16=$ Cottonwood Mountains $17=$ Nova basin

$18=P$ anamint Valley

$19=P$ anamint Mountains

$20=$ Copper Canyon basin

21 = Amargosa River V alley

$22=$ Resting Spring Range

23 = China Ranch basin

$24=$ Dumont Hills

$25=$ Kingston Range

$26=$ Kingston $\mathrm{W}$ ash

27 = Shadow V alley basin

Figure 1. Location map and place names, Death Valley region, Nevada and California 
within these deposits. Under the areas of alluvial cover, these changes are concealed, but much can be surmised by interpolating and extrapolating from adjacent exposures, in combination with borehole and geophysical data.

This report presents a facies analysis of Tertiary basin-filling deposits for the Death Valley region, exclusive of the named volcanic units in the vicinity of the southwestern Nevada volcanic field. The purpose of this report is to assemble the available information on lithologic variations within the Cenozoic basin-filling sequences throughout the Death Valley region, based on surface mapping data, drill-hole data, and geophysical constraints. These data are then applied to development of a generalized characterization of the lithologic variability of the basin fills, along with available qualitative information about the relative hydrologic properties of the different lithologies.

\section{Cenozoic Stratigraphy of the Death Valley Region}

This lithologic study addresses primarily the southern part of the Death Valley groundwater flow system of the southwest Great Basin, Nevada and California (Bedinger and others, 1989). In the Cenozoic, this region has undergone a complex history of transtensional deformation, which has ultimately created a tectonic landscape that is a mosaic of alternating, narrow basins and ranges (basin-range topography). As the tectonic basins of this region formed and evolved, they were filled by a locally thick sequence of terrestrial sediments and volcanic rocks, which provide a record of the Cenozoic environmental history of this region. This history shows three major types of changes in this region over the last 40 m.y., each of which has had a major impact on the lithologies in the basin-fill sequences (Fridrich and others, 2000):

- A progressive change from the initially humid conditions of the Late Eocene, to the very arid conditions of today. This climatic change is reflected in a change from a dominance of fluvial cobble conglomerates and freshwater limestones in the oldest basin-fill sequences to a dominance of alluvial fan breccias and playa claystones in the youngest deposits. In addition, the early 
humid conditions fostered the production of clay as a product of weathering, a process that has diminished strongly with time.

- Progressive tectonic fragmentation of the region. The earliest Cenozoic tectonism apparently created very broad and shallow basins. Basin-range topography, as we know it today, first developed in the Death Valley region from $\sim 14$-to- $12 \mathrm{Ma}$, it evolved through three successive tectonic episodes, and it is still actively evolving in the southwesternmost part of the Death Valley region, and to the west. The tectonic evolution of this region is reflected in changes in sedimentation patterns, from an earlier pattern dominated by regional-scale fluvial transport to a later pattern dominated by sedimentary transport and deposition largely confined within relatively small intermontane basins with local sediment sources.

- Volcanic input to the basins as a result of the strong pulse of volcanism in mid and late Miocene time, primarily from the southwestern Nevada volcanic field and to a lesser extent from the central Death Valley volcanic field. From $\sim 40$ to $15 \mathrm{Ma}$, the Death Valley region had no local volcanism. A variety of volcanic fields were the source for distal tuffs that reached the region in this initial prevolcanic interval. Most of these volcanic source areas were in central and southern Nevada and together they defined a slowly southward-migrating pattern of volcanism. The migrating pattern of volcanism eventually moved into the Death Valley region at $\sim 15 \mathrm{Ma}$, peaked with very high eruption rates between 13.5 and $11 \mathrm{Ma}$, and then declined with time as the focus of volcanism migrated generally westward, largely moving out of the region at $\sim 6 \mathrm{Ma}$. This volcanic history is reflected in changing input of both primary volcanic units and of volcaniclastic detritus into basin fills throughout this history. Moreover, the volcanism and related tectonism provided the heat for local hydrothermal activity, which has greatly reduced the permeability of some basin-fill deposits, especially of nonwelded tuffs and ashy sediments.

Tertiary strata of the Death Valley region have been subdivided into seven unconformity-bounded sequences (see fig. 8; Snow and Lux, 1999; Fridrich and others, 
2000). These seven sequences can, in turn, be generalized into three sequences according to their relation to the tectonic evolution of the region: (1) an early extensional sequence that predates the formation of basin-range topography, (2) a synextensional sequence that corresponds to the major period of formation of basin-range topography in this region, and (3) a 6-Ma-to-present late extensional to post-extensional sequence.

The base of the early extensional sequence, which is the basal Tertiary contact, varies in age from $\sim 40$ to $\sim 25 \mathrm{Ma}$ over different parts of the region. This variation appears largely to reflect progressive burial of topography, as discussed below. In general the basal Tertiary contact youngs to the west and south within the Death Valley region. The contact between the early extensional and synextensional sequences varies from $\sim 14$ to $\sim 12 \mathrm{Ma}$ in different locales, reflecting local variations in the onset of basinrange tectonism, or the change in sedimentary depositional environments that occurred as a consequence of basin-range tectonism. The basal synextensional contact generally youngs to the northwest. The contact between the synextensional and the late extensional sequences varies from $\sim 10 \mathrm{Ma}$ in the northeasternmost part of the Death Valley region to $\sim 6 \mathrm{Ma}$ in Death Valley and west of it. Above this contact the strata are late extensional from eastern margin of Death Valley westward, and they are post-tectonic to the east of Death Valley. The early extensional sequence was prevolcanic up to $\sim 15 \mathrm{Ma}$, when andesite-rhyolite volcanism gradually migrated into the region from the north and east. The synextensional sequence coincided with the dominant period of volcanism in the region, which was bimodal in character. The late- to post-extensional sequence corresponds to a period of waning, largely basaltic volcanism in the Death Valley region.

\section{Early Extensional Sequence}

Sedimentary strata deposited before the creation of basin-range topography are widely distributed throughout the Death Valley region. The major unifying characteristics of these early extensional deposits are that: (1) lateral changes in lithology in these strata are mostly very gradual throughout the region, (2) abrupt lateral thickness changes in the lowermost ( 40 to $27 \mathrm{Ma}$ ) part of this sequence apparently reflect burial of moderately high-relief topography at the basal Tertiary surface, some of which evidently was tectonic in origin, and (3) in the few cases where abrupt lateral facies and thickness 
changes are found in the middle and upper (27 to 14 Ma) part of this sequence, they correspond spatially to a small number of long-abandoned structures that are locally exposed within the modern-day ranges, rather than to topographically expressed (modern-day) basin-range boundaries.

Lithologically, the early extensional sequence can be divided into three major packages, as a generalization. The oldest of these packages largely ranges in age from $\sim 40$ to $\sim 25 \mathrm{Ma}$ and consists dominantly of conglomerates and lesser basal breccias, both of cobble-to-boulder-size, mostly in clay-rich matrices. The next package covers the age range from $\sim 25$ to $\sim 19 \mathrm{Ma}$ and consists mostly of interbedded fluvial sandstones, freshwater limestones and marls, and lesser playa claystones and pebble conglomerates. Together, these two oldest lithologic packages have been named the Titus Canyon Formation in the Grapevine Mountains (Reynolds, 1974), in the northern Funeral Mountains (Wright and Troxel, 1993), and in an area immediately west of the Nevada Test Site (Fridrich, Minor, Ryder, and others, 1999). They have also been called the Ubehebe Formation in the Cottonwood Mountains (Snow and Lux, 1999), the conglomerate and limestone members of the Amargosa Valley Formation in the southeast Funeral Mountains (Cemen and others, 1999), and the brown gravel unit of the rocks of Joshua Hollow on the northeast side of Bare Mountain (Monsen and others, 1992). In the Rock Valley area, the equivalent rocks have been called the rocks of Winapi Wash (J. Yount, USGS, oral comm., 1992). Earlier, they were mapped as the Horse Springs Formation (Hinrichs, 1968), a lithologically similar, but younger (20-12 Ma) unit exposed in the area east of Las Vegas (Bohannon, 1984). On most other maps of the region, the strata of these oldest two lithologic packages have been lumped with other strata as older Tertiary sediments.

Strata that range in age from $\sim 19$ to $\sim 17 \mathrm{Ma}$ are apparently absent throughout the Death Valley region, owing to nondeposition or erosion (Fridrich and others, 2000). The uppermost of the three sections of the early extensional sequence, above this missing section, exhibits greater lithologic variability than all of the older Cenozoic strata. This uppermost sequence is $\sim 16 \mathrm{Ma}$ at the base and, as discussed above, has a top that ranges in age from $\sim 14$ to $\sim 12 \mathrm{Ma}$. Volcanic rocks within this uppermost early extensional sequence consist of andesitic agglomerates and lavas of the central Death Valley volcanic 
field in the southern part of the region and rhyolitic tuffs of the southwestern Nevada volcanic field in the northern part of the region. Both of these volcanic sections were deposited on a basal ( $\sim 16$ to $\sim 14 \mathrm{Ma}$ ) section of sediments, mostly arkosic fluvial sandstones (mostly redbeds) in the south and fine-grained tuffaceous sediments with locally thick interbedded conglomerates in the north. Moreover, both volcanic sections interfinger laterally with arkosic red sandstones that constitute the majority of this section in the central part of the region. Volcanic units of the southwestern Nevada volcanic field are in general not considered in this report. Only in those areas where tuffs of probable affinity to the southwestern Nevada volcanic field are intercalated with coeval Tertiary sediments and have not been explicitly identified are they included as part of the undifferentiated Tertiary basin-filling rocks.

This uppermost of the three early extensional sections includes the unnamed redbed sections intermittently exposed on either side of the Beatty Junction cutoff road from $\sim 2$ to $\sim 9 \mathrm{~km}$ south-southeast of Hell's Gate, at the northwest limit of the Funeral Mountains (Wright and Troxel, 1993). It also includes the Panuga Formation of the Cottonwood Mountains (Snow and Lux, 1999). In the southeastern Funeral Mountains, it is the upper part of the Amargosa Valley Formation. In the Kingston Range, the equivalent section is the lower part of the Resting Spring Formation, which is composed predominantly of sandstone, limestone, and andesite (Fowler and Calzia, 1999; Friedmann, 1999). In the southwestern Nevada volcanic field, this section includes a basal part, which has variably been called the Tunnel Formation (in the northern part of the volcanic field, where it consists dominantly of bedded tuffs) or the rocks of Pavits Spring (in the southern part of the volcanic field, where it consists dominantly of tuffaceous sandstones), among other names, and an upper ( 14-to- 12-Ma) part, which consists of volcanic formations including the Lithic Ridge Tuff and associated units, the tuffs and lavas of the Crater Flat Group, and the Wahmonie Formation (Sawyer and others, 1994).

Hydrologically, the early extensional sequence of the Death Valley region shows a range of behaviors. The coarse clastic sediments with clay-rich matrices that constitute the majority of the lowermost part of this sequence are predominantly confining units. The best evidence for this is the common localization of springs at contacts between Late Proterozoic quartzites and these clay-matrix sediments, especially where the quartzites 
are exposed uphill from the Tertiary sequence. These quartzites are generally impermeable except where they are locally fractured; they have been classified as part of the lower clastic aquitard of the Death Valley region (Winograd and Thordarson, 1972). The setting of these hillside springs suggests that the clay-matrix sediments of the lower part of the early extensional sequence are even less permeable. Parts of the volcanic sections of the uppermost (16-to- 12-Ma) part of the early extensional sequence are known to be aquifers, especially the densely welded tuffs. For example, the tuffs of the Crater Flat Group, which have been penetrated by numerous drill holes into Yucca Mountain and Crater Flat, have been shown to be good water producers in many of these wells (Waddell and others, 1984; Luckey and others, 1996). The other strata of the early extensional group largely have unproven hydrologic characteristics, but probably cover a broad range of properties. Where these sediments are strongly tuffaceous, they typically also are quite altered and probably are impermeable. The arkosic sandstones in this sequence probably are only marginal aquifers, because they typically contain abundant tuffaceous material that is strongly diagenetically altered. Limestones, as a rock type, should be a good aquifer, but existing data suggest that the limestones in this sequence are very discontinuous, which would strongly limit their importance as aquifers, even if they are very permeable.

The hydrologic behavior of the early extensional sequence also depends upon the structural setting in addition to the lithologic factors discussed above. Deposition of this sequence predated most of the strong transtensional deformation that has occurred in the Death Valley region in the Cenozoic, so these rocks are tectonically disrupted in much of the region. This probably has resulted in structural dismemberment of the aquifers in this sequence in many areas. However, the confining units in this sequence are also dismembered in many areas and are strongly faulted in most of the region; hence these confining units, at a minimum, are probably rather leaky in most areas. At Yucca Mountain, it is clear from the difference in head between the deep Paleozoic carbonate aquifer and the welded tuff aquifer, in well USW p\#1, that the impermeable strata in the lower part of the early extensional sequence, which intervene between these two aquifers, act as an effective confining unit. Thermal and carbon-isotopic data on groundwater 
under Yucca Mountain also show, however, that this confining unit leaks along the major faults cutting the mountain (Fridrich and others, 1994).

In summary, the lower and middle part of the early extensional sequence is typically a leaky confining unit, and the upper part is mixed in properties as a function of locale. In some areas it is a leaky confining unit like the underlying rocks and elsewhere it is a moderately permeable aquifer like most of the overlying units.

\section{Synextensional Sequence}

In the early extensional sequence, lateral changes in stratigraphic thicknesses and lithologic characteristics are very gradual in all directions, in general. In particular, there are no appreciable changes across the crests or range-fronts of present-day mountain ranges. Locally, the uppermost ( 14-to- $\sim 12-\mathrm{Ma})$ part of the $\sim 40$-to $\sim 12-\mathrm{Ma}$ strata of the region includes some tectonic sediments that are related to the initial development of a small number of the most major basin-range faults that were active primarily after $12 \mathrm{Ma}$. These earliest group of sediments that are synextensional (relative to the major basinrange-forming tectonic episode) consist primarily of coarse alluvium. At $\sim 12 \mathrm{Ma}$, the shift to predominantly local provenance of the clastic sediments, which had from $\sim 14$ to $\sim 12$ Ma been confined to a very localized range, was abruptly extended over the whole central and eastern part of the region, reflecting the initial uplift of the modern-day mountain ranges, excepting those west of the Death Valley physiographic feature. This major basin-range-forming tectonic episode, which began locally at $\sim 14$ and became regionally extensive at $\sim 12 \mathrm{Ma}$, continued until about $10 \mathrm{Ma}$ in the northeasternmost part of the Death Valley region and to $\sim 6 \mathrm{Ma}$ in the vicinity of the Northern Death Valley/Furnace Creek fault.

The synextensional part of the fill of each of the region's basins is essentially a separate formation in each basin. Each of these synextensional basin fills has considerable individuality in its thicknesses, lithologies, provenance of clasts, and many other features. Moreover, lateral variations in these features are found within each of these basin fills that (1) commonly bear a relationship to the northwestward migration of the focus of tectonism during the synextensional episode, and (2) commonly exceed the variability of the early extensional sequence across the entire region. Moreover, the 
diversity of lithologies in the synextensional strata exceeds that of any of the younger or older basin-fill deposits because: (1) the climate during the synextensional episode was transitional between the relatively humid before and the relatively arid conditions after this time period, resulting in the interlayering of sedimentary rocks deposited in varying climatic conditions, and (2) volcanic activity peaked in the synextensional episode, resulting in a greater abundance and diversity of volcanic rocks than that found in both the younger and older deposits. Because of the very high rate of felsic pyroclastic volcanic activity, early ( 14-to- 10-Ma) synextensional alluvial deposits of this age range typically have matrices that contain significantly more tuffaceous material than do any younger or older alluvium of the region.

As variable as the lithologies are in the synextensional sequence, and as much as they vary in character between the different basins of the region, there are certain generalizations that can be made about the characteristics of these deposits, as a function of geographic position:

(1) In the vicinity of the southwestern Nevada volcanic field, the major lithologies in the synextensional sequence consist of moderately to densely welded tuffs, alluvial and landslide breccias, as well as some nonwelded tuffs and lavas (Byers and others, 1976; Sawyer and others, 1994). The majority of these deposits are at least moderately permeable, except in the area immediately in and around the central caldera complex of the volcanic field, where hydrothermal alteration has destroyed much of the original permeability (Winograd and Thordarson, 1975; Blankennagel and Weir, 1973; Laczniak and others, 1996). Moreover, the horizons within these strata that are relatively impermeable are sufficiently faulted in most cases that they probably are not effective confining units. The approximate areal extent of volcanic rocks derived from the southwestern Nevada volcanic field is defined to the west by outcrops in the Funeral and Grapevine Mountains, to the south and southeast by borehole intercepts along U.S. Highway 95 south of Yucca Mountain and in northwestern Frenchman Flat, and to the east by depositional pinchouts near the Nye County-Lincoln County line. The area in which this characterization applies includes the synextensional sections found in the following alluvial basins: Yucca Flat, Frenchman Flat, Jackass Flats, Crater 
Flat, Oasis Valley basin, and Sarcobatus Flat (fig.1). In all of these basins, these synextensional deposits overlie early extensional strata that are leaky confining units. The deep carbonate aquifer is known or presumed to underlie Yucca Flat, Frenchman Flat, and at least parts of the Crater Flat and Jackass Flats basins, but is probably absent under the majority of the Sarcobatus Flat basin. In the vicinity of the southwestern Nevada volcanic field, the synextensional section consists of the tuffs and lesser lavas of the Paintbrush, Timber Mountain and Thirsty Canyon Groups, along with many lesser volcanic units and interbedded, largely unnamed sediments.

(2) In the area of the central Death Valley rhombochasm (Wright and others, 1991), which extends from the east flank of the Panamint Mountains eastward to the Resting Spring Range and from the southwest flank of the Funeral Mountains southward to southern Death Valley fault zone, synextensional basin fills are largely sedimentary at the base - including conglomeratic sandstones and breccias - but otherwise consist primarily of bimodal (dacite-basalt) volcanic rocks and tuffaceous sediments (McAllister, 1970; 1973; 1974; Cemen and others, 1985; Wright and others, 1991; Greene, 1997). Throughout the majority of this area, these rocks are hydrothermally altered to the point where the original permeability has been largely destroyed, except perhaps in some of the coarsest sediments, locally found near the base of synextensional sections and near the margins of the basin. Significant permeability probably has survived in these deposits only in very limited locales. The only deposits recognized as significant aquifers within this synextensional basin-fill sequence are breccias found along the western flank of the Resting Spring Range (Cemen, 1983) that are presumed to project westward under the adjacent part of the Amargosa River Valley. Some permeable breccias may also be present immediately adjacent to the southwestern flank of the Funeral Mountains. Otherwise, the synextensional basin fill deposits of the central Death Valley rhombochasm probably are fairly impermeable. The early extensional sequence is structurally omitted within most of the Death Valley rhombochasm (Wright and others, 1999); synextensional deposits are structurally complex and have been included as part of the Amargosa Chaos in the 
southwestern part of the basin (Wright and Troxel, 1984; Topping, 1993). In the rest of the basin, the major named parts of the synextensional basin fill include the Artist Drive Formation and the coeval Shoshone volcanics as the major units (Wright and others, 1991). Paleozoic carbonates probably are present beneath the easternmost part of this basin, but are likely to be tectonically thinned and discontinuous throughout most of the central Death Valley rhombochasm.

(3) In the area of the China Ranch basin, Dumont Hills, and around the perimeter of the Kingston Range, synextensional Cenozoic deposits consist largely of very coarse alluvium and rock-avalanche breccias, which are probably quite permeable, and lesser amounts of impermeable playa claystones (Fowler and Calzia, 1999; Prave and McMackin, 1999; Friedmann, 1999). The playa claystones are present in restricted areas where they typically are completely surrounded by alluvium and breccias; hence, it is improbable that they form effective confining units because groundwater may flow around these areas of impermeable sediments. The limited exposures of synextensional sediments in the Pahrump Valley are of sediments similar to those in the China RanchKingston Range area. The synextensional deposits in this area are largely unnamed but include the China Ranch beds and the fill of the Shadow Valley basin on the south side of the Kingston Range (Prave and McMackin, 1999; Friedmann, 1999).

(4) The Amargosa Desert is the most difficult basin to characterize hydrogeologically within the southern Death Valley ground-water system, partly because this huge area of alluvial cover is a composite of several structural basins. Additionally, Cenozoic strata exposed on different sides of this basin differ strongly in their lithologies, suggesting the presence of pronounced lateral facies changes. Sediments having the characteristics described in all of the above three areas are found in different parts of the Amargosa Desert basin. The synextensional sequence (along with the uppermost part of the underlying early extensional sequence) includes a large thickness of permeable densely welded tuffs in the three areas that border the western arm of the Amargosa Desert, namely, the Crater Flat basin (Fridrich, 1999; Fridrich, Whitney, and others, 1999), the 
Bullfrog Hills (Maldonado, 1990; Fridrich, Minor, and Mankinen, 1999), and the hills along the northern flank of the Funeral Mountains, just south of the Bullfrog Hills (Wright and Troxel, 1993). Aeromagnetic data indicate, however, that equivalent volcanic rocks are present only in a spotty fashion under the alluvium that intervenes between the exposures in these three areas (Grauch and others, 1999; Blakely and others, 2000). The drilling evidence that exists in this intervening area (the western arm of the Amargosa Desert) indicates that the basin fill is mostly sedimentary, consisting of an upper permeable part, mostly alluvium, and a lower part, consisting mostly of tuffaceous sediments that probably are not very permeable owing to diagenetic alteration. In the eastern arm of the Amargosa desert, the few synextensional deposits that are exposed closely resemble those of basins to the south and east (category 3 , above) and are likely to be permeable. These sediments overlie an impermeable early extensional sequence; hence the synextensional aquifer in this area may be separated from the underlying deep carbonate aquifer in at least part of the area by a leaky, heavily faulted and probably discontinuous confining unit. The central part of the Amargosa Desert is a north-trending trough, which is much deeper than the east and west arms of the Amargosa Desert basin-complex (Blakely and others, 1999). The basin fill in the northern part of this trough resembles that of the western arm of the Amargosa Desert (Oatfield and Czarnecki, 1989; Carr and others, 1995), whereas that of the southern part of the trough is more similar to the central Death Valley rhombochasm, but with a larger proportion of interbedded sandstones, which probably have moderate to low permeability (Naff, 1973). In summary, the basin fill includes a widespread high quality alluvial aquifer in the east and west arms of the Amargosa Desert and in the northern part of the central trough. Permeability of the basin-fill decreases southward within the southern part of the Amargosa trough (Oatfield and Czarnecki, 1989; Naff, 1973), based on the southward increasing abundance of altered nonwelded tuffs. Southward along the course of the Amargosa River, transmissive rocks likely are present again in a narrow corridor under this valley from just south of Eagle Mountain to the town of Shoshone, where exposed basin fill deposits consist of 
less permeable lithologies (Morrison, 1999). Further south, the Amargosa River flows through basin fill of the China Ranch area, which is permeable except in a few areas dominated by playa sediments (Prave and McMackin, 1999; Morrison, 1999). The locations of active springs and Pleistocene spring deposits along the course of the Amargosa River, as well as the stretches where this river flows most of the year, tend to mirror the changes in lithology of basin-filling deposits exposed along the course of this river.

\section{Late extensional/post-extensional sequence}

As discussed above, the synextensional sequence ends upsection at a contact that varies in age from $\sim 10 \mathrm{Ma}$ in the northeastern part of the Death Valley region to $\sim 6 \mathrm{Ma}$ in the vicinity of Death Valley, and to the west. East and north of the Death Valley rhombochasm, this overlying section is post-tectonic and consists largely of alluvium and lesser sediments of other types, mainly playa sediments. Within the Death Valley rhombochasm and to the west, these deposits are late extensional because extensional tectonism has continued in most of this area to the present, but the lithologies are basically the same as where this section is post-tectonic. Because the volumetrically dominant alluvial deposits of this youngest section largely postdate felsic pyroclastic volcanism in the region, the alluvium is not particularly tuffaceous. In most of the region, this alluvium has never been deeply buried and generally it is poorly consolidated. The majority of the late extensional/post-extensional sequence is therefore permeable. The major places where it is not permeable is in those areas where it consists mostly of playa sediments, such as much of the Furnace Creek basin (in the northernmost part of the Death Valley rhombochasm), and on the floor of Death Valley physiographic feature.

\section{Stratigraphic Setting of Tertiary Basin-Filling Deposits}

Regional ground-water flow models of the Death Valley region (IT Corp., 1996; D'Agnese and others, 1997) have described the Tertiary basin-filling rocks using a hydrogeologic unit that encompasses the entire undifferentiated sequence of Tertiary 
basin fill. When modeled as a single hydrogeologic unit, these rocks appear in various stratigraphic scenarios, described below in order of their increasing complexity.

In case 1 (fig. 2), Tertiary sedimentary rocks directly underlie Quaternary alluvium. Sedimentary sections are free of thick intervals of volcanic rocks, although the sedimentary units may have a volcaniclastic component. This is the case in Las Vegas Valley and the Indian Springs area where the Middle Miocene Horse Springs Formation is overlain by the Las Vegas Formation and Quaternary valley fill (Bohannon, 1984; Plume, 1989); in Hampel Wash and Rock Valley on the Nevada Test Site where the "rocks of Winapi Wash" and the "rocks of Pavits Spring" are overlain by Quaternary alluvium (Hinrichs, 1968); and in Kingston Wash and the northern part of the Shadow Valley basin where Tertiary conglomerates and megabreccias are overlain by Quaternary sediments (Friedmann, 1999; Prave and McMackin, 1999).

In case 2 (fig. 2) Tertiary sedimentary rocks underlie a thick sequence of regionally extensive ash-flow tuffs derived from the southwestern Nevada volcanic field. The volcanic units are thick enough and well enough known to be modeled as their own hydrogeologic units (rather than being lumped with the Tertiary sediments as in case 3 ). Situations like case 2 occur in northwestern Frenchman Flat, Yucca Flat and beneath portions of southern Yucca Mountain (fig. 1). As the volcanic pile thickens proximal to the volcanic sources, boreholes do not penetrate the entire thickness of the volcanic rocks. Thus, the extent of the Tertiary sediments beneath the volcanic rocks is unknown close to the volcanic source.

In case 3 (fig. 2), Tertiary sediments are interbedded with Tertiary volcanic rocks such that neither can be modeled as a separate hydrogeologic unit at the scale of a regional model. This situation occurs in much of the central Death Valley volcanic field, Furnace Creek Wash and the Amargosa Desert. This is the approach used in analyzing the outcrop and borehole data presented in this report.

In case 4 (fig. 2), named volcanic units of the southwestern Nevada volcanic field interfinger at their distal edges with coeval Tertiary sediments. This is the most complex situation to model because of the potential for repetition of hydrogeologic units something to be avoided. Situations like this occur in narrow bands near the margins of 
CASE 1

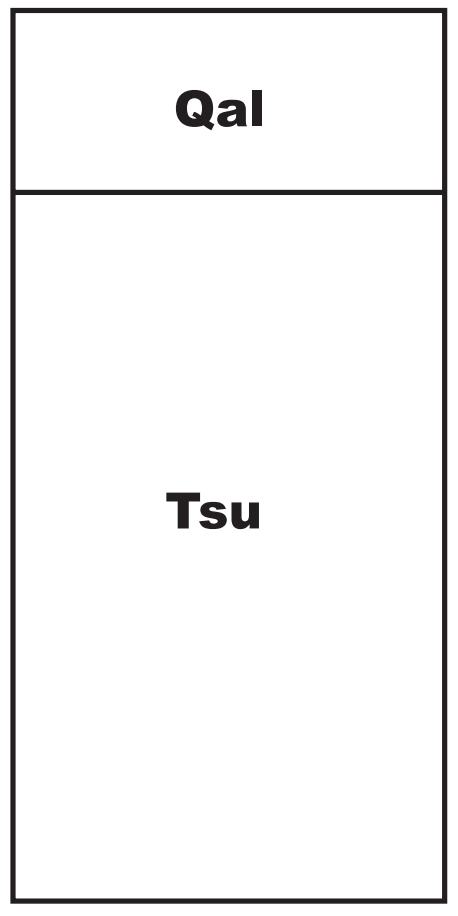

CASE 3

\begin{tabular}{|c|}
\hline Qal \\
\hline Tvu \\
\hline Tsu \\
\hline Tvu \\
\hline Tsu \\
\hline Tvsu \\
\hline
\end{tabular}

CASE 2

\begin{tabular}{|c|}
\hline Qal \\
\hline Tm \\
\hline Tp \\
\hline Tc \\
\hline Tb \\
\hline Tvsu \\
\hline
\end{tabular}

Miocene volcanic rocks of the southwestern Nevada volcanic

Tm Timber Mountain Group

Tp Paintbrush Group

Tc Crater Flat Group

$\mathrm{Tb}$ Belted Range Group
Types of Tertiary basin-filling

Tvsu Tertiary sedimentary and volcanic rocks, undivided

Tsu Tertiary sedimentary rocks, undivided

Tvu Tertiary volcanic rocks, undivided

Figure 2. Diagrammatic examples of possible stratigraphic position of undifferentiated Tertiary volcanic and sedimentary rocks. 
the volcanic field; for example, in central Frenchman Flat and in some of the Nye County Early Warning Drilling Program (EWDP) boreholes to the south of Yucca Mountain.

\section{Methods of Study}

\section{Outcrop Data}

Various workers have collected outcrop data from Tertiary strata during the course of studies attempting to reconstruct the Tertiary extensional history of the region. Outcrops of Tertiary strata are present mostly as stranded, rotated successions along range fronts. In a number of cases, the base of the Tertiary section is exposed, but not the top; this represents a possible source of bias in the data. Uncertainty also exists in how far to project the geology preserved in these outcrops into the subsurface. Tables 1 and 2 present a compilation of outcrop data from throughout the region; a total of 33 localities are presented. Locations of the outcrop data are shown in figure 3. The data compilation includes total thickness, aggregate thickness of the volcanic component (including rhyolite and basalt flows, tuff, and air-fall deposits), aggregate thickness of the sedimentary component (including conglomerate, megabreccia, sandstone, siltstone, and limestone), and the thickness of the limestone portion of the sedimentary sequence.

\section{Subsurface Data}

Boreholes have been drilled in the Tertiary basin fill for various reasons including mineral exploration, water wells, test holes on the Nevada Test Site and as part of the site characterization at Yucca Mountain. Most of the boreholes do not penetrate the entire Tertiary section, leading to an underestimation in the total thickness of the section, and a bias towards data from the upper part of the section. Data quality is variable -- some of the data from the Amargosa Desert are from driller's logs where the Tertiary sedimentary section may be reported as "gravel", "colluvium" or "paleocolluvium". Tables 3 and 4 present a compilation of borehole data from throughout the region, a total of 64 localities. Borehole locations are shown in figure 3. Many more boreholes are available, but these holes were chosen to mimic the density of the outcrop data, provide a broad spatial distribution, include the deepest boreholes, and include those holes that were representative of a closely-spaced group of boreholes. 


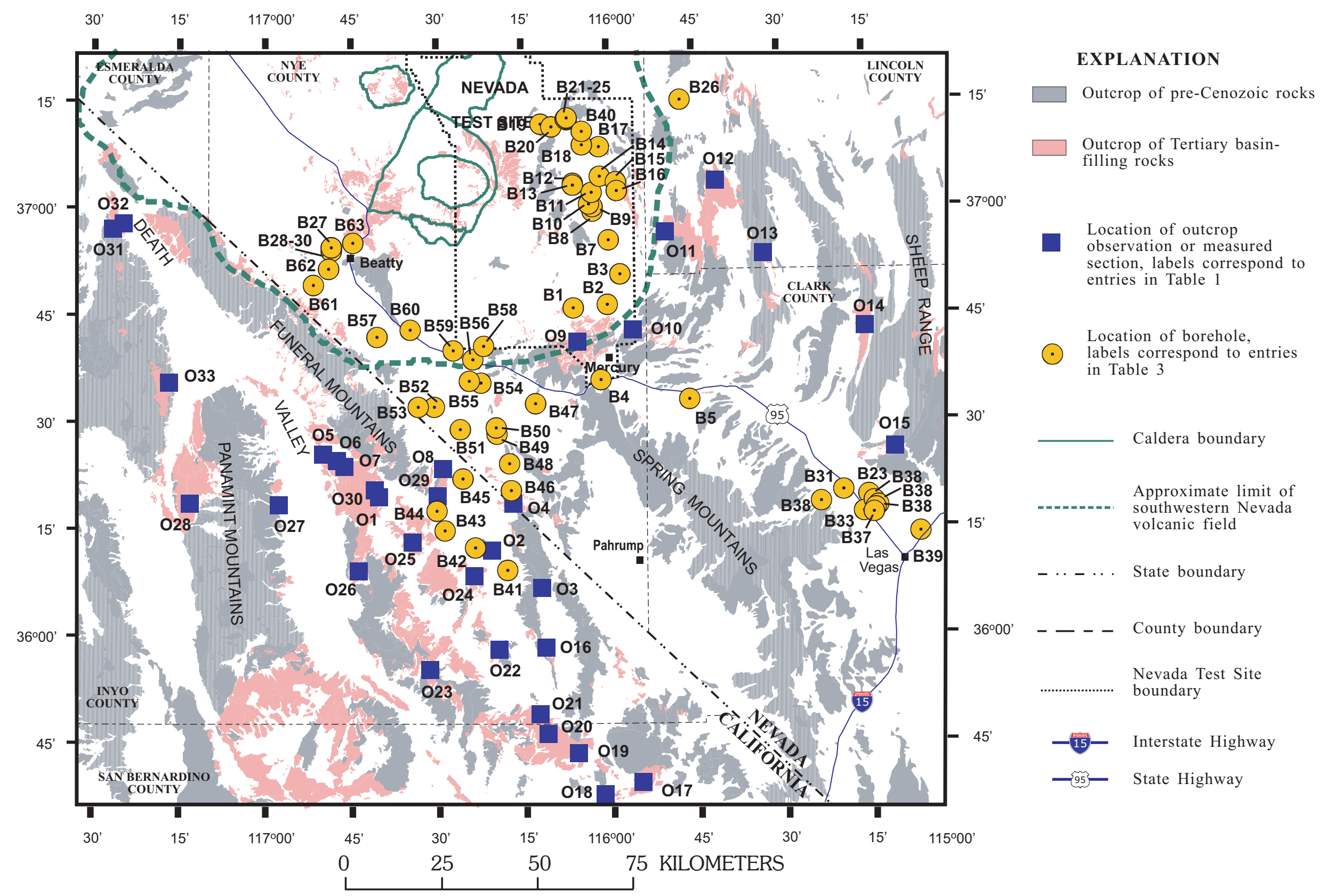

Figure 3. Location map of outcrops and boreholes used in this study. 
Table 1. Location of outcrop data used for facies analysis

\begin{tabular}{|c|c|c|c|c|}
\hline $\begin{array}{l}\text { Location } \\
\text { Number }\end{array}$ & Location Name & Latitude & Longitude & Reference \\
\hline $\mathrm{O} 1$ & Ryan Mine & $36^{\circ} 18^{\prime} 38^{\prime \prime}$ & $116^{\circ} 40^{\prime} 16^{\prime \prime}$ & Niemi and others (2001), fig. 2; Cemen and others (1985). \\
\hline $\mathrm{O} 2$ & Eagle Mountain & $36^{\circ} 11^{\prime} 40^{\prime \prime}$ & $116^{\circ} 20^{\prime} 46^{\prime \prime}$ & Niemi and others (2001), fig. 2 and Appendix 1. \\
\hline $\mathrm{O} 3$ & East of Resting Spring Range & $36^{\circ} 06^{\prime} 27^{\prime \prime}$ & $116^{\circ} 12^{\prime} 03^{\prime \prime}$ & Niemi and others (2001), fig. 2 and Appendix 1. \\
\hline $\mathrm{O} 4$ & North of Resting Spring Range & $36^{\circ} 18^{\prime} 18^{\prime \prime}$ & $116^{\circ} 16^{\prime} 53^{\prime \prime}$ & Cemen (1983); Denny and Drewes (1965) \\
\hline O5 & Black Mountains, section B-B' & $36^{\circ} 25^{\prime} 22^{\prime \prime}$ & $116^{\circ} 49^{\prime} 59^{\prime \prime}$ & Niemi and others (2001), fig. 14; Greene (1997). \\
\hline O6 & Black Mountains, section E-E' & $36^{\circ} 24^{\prime} 26^{\prime \prime}$ & $116^{\circ} 47^{\prime} 36^{\prime \prime}$ & Niemi and others (2001), fig. 14; Greene (1997). \\
\hline O7 & Black Mountains, section G-G' & $36^{\circ} 23^{\prime} 40^{\prime \prime}$ & $116^{\circ} 46^{\prime} 21^{\prime \prime}$ & Niemi and others (2001), fig. 14; Greene (1997). \\
\hline $\mathrm{O} 8$ & Bat Mountain north & $36^{\circ} 21^{\prime} 04^{\prime \prime}$ & $116^{\circ} 28^{\prime} 59^{\prime \prime}$ & Cemen and others (1985), fig. 4; Cemen and others (1999), fig. 7. \\
\hline O9 & Hampel Wash & $36^{\circ} 41^{\prime} 04^{\prime \prime}$ & $116^{\circ} 05^{\prime} 28^{\prime \prime}$ & Hinrichs (1968). \\
\hline $\mathrm{O} 10$ & Mercury quadrangle & $36^{\circ} 42^{\prime} 43^{\prime \prime}$ & $116^{\circ} 55^{\prime} 53^{\prime \prime}$ & Barnes and others (1982). \\
\hline O11 & Nye Canyon & $36^{\circ} 56^{\prime} 28^{\prime \prime}$ & $116^{\circ} 49^{\prime} 59^{\prime \prime}$ & Hinrichs and McKay (1965). \\
\hline $\mathrm{O} 12$ & Buried Hills & $37^{\circ} 03^{\prime} 42^{\prime \prime}$ & $116^{\circ} 41^{\prime} 01^{\prime \prime}$ & Tschanz and Pampeyan (1970); Guth and others (1988). \\
\hline $\mathrm{O} 13$ & Gravel Canyon, Pintwater Range & $36^{\circ} 53^{\prime} 25^{\prime \prime}$ & $116^{\circ} 32^{\prime} 55^{\prime \prime}$ & Longwell and others (1965); Guth and others (1988). \\
\hline $\mathrm{O} 14$ & Black Hills basin & $36^{\circ} 42^{\prime} 59^{\prime \prime}$ & $116^{\circ} 15^{\prime} 11^{\prime \prime}$ & Guth and others (1988). \\
\hline $\mathrm{O} 15$ & Gass Peak basin & $36^{\circ} 25^{\prime} 55^{\prime \prime}$ & $116^{\circ} 10^{\prime} 14^{\prime \prime}$ & Guth and others (1988). \\
\hline $\mathrm{O} 16$ & Southern Resting Spring Range & $35^{\circ} 57^{\prime} 57^{\prime \prime}$ & $116^{\circ} 11^{\prime} 23^{\prime \prime}$ & Wright (1999). \\
\hline $\mathrm{O} 17$ & Kingston Wash & $35^{\circ} 38^{\prime} 54^{\prime \prime}$ & $116^{\circ} 54^{\prime} 49^{\prime \prime}$ & Prave and McMackin (1999), fig. 9. \\
\hline $\mathrm{O} 18$ & Western Kingston Wash & $35^{\circ} 37^{\prime} 15^{\prime \prime}$ & $116^{\circ} 01^{\prime} 28^{\prime \prime}$ & Prave and McMackin (1999), fig. 9. \\
\hline O19 & Dumont Hills, section E & $35^{\circ} 43^{\prime} 05^{\prime \prime}$ & $116^{\circ} 05^{\prime} 51^{\prime \prime}$ & Prave and McMackin (1999), fig. 6. \\
\hline $\mathrm{O} 20$ & Dumont Hills, section C & $35^{\circ} 45^{\prime} 49^{\prime \prime}$ & $116^{\circ} 11^{\prime} 07^{\prime \prime}$ & Prave and McMackin (1999), fig. 6. \\
\hline $\mathrm{O} 21$ & Amargosa Canyon, China Ranch & $35^{\circ} 48^{\prime} 32^{\prime \prime}$ & $116^{\circ} 12^{\prime} 31^{\prime \prime}$ & Holm and others (1994), fig. 11. \\
\hline $\mathrm{O} 22$ & Dublin Hills & $35^{\circ} 57^{\prime} 51^{\prime \prime}$ & $116^{\circ} 19^{\prime} 35^{\prime \prime}$ & Chesterman (1973). \\
\hline $\mathrm{O} 23$ & Salsberry Pass & $35^{\circ} 55^{\prime} 00^{\prime \prime}$ & $116^{\circ} 31^{\prime} 36^{\prime \prime}$ & Wright and Troxel (1984). \\
\hline $\mathrm{O} 24$ & Greenwater Range, Brown Peak & $36^{\circ} 08^{\prime} 06^{\prime \prime}$ & $116^{\circ} 23^{\prime} 49^{\prime \prime}$ & Wright and others (1981). \\
\hline $\mathrm{O} 25$ & Greenwater Range, Funeral Peak area & $36^{\circ} 13^{\prime} 00^{\prime \prime}$ & $116^{\circ} 34^{\prime} 27^{\prime \prime}$ & Drewes (1963). \\
\hline $\mathrm{O} 26$ & Copper Canyon basin & $36^{\circ} 08^{\prime} 55^{\prime \prime}$ & $116^{\circ} 43^{\prime} 57^{\prime \prime}$ & Drewes (1963). \\
\hline $\mathrm{O} 27$ & Trail Canyon & $36^{\circ} 18^{\prime} 13^{\prime \prime}$ & $116^{\circ} 57^{\prime} 44^{\prime \prime}$ & McKenna and Hodges (1990). \\
\hline $\mathrm{O} 28$ & Nova basin & $36^{\circ} 18^{\prime} 27^{\prime \prime}$ & $116^{\circ} 13^{\prime} 18^{\prime \prime}$ & Hodges and others (1989). \\
\hline O29 & Bat Mountain south & $36^{\circ} 19^{\prime} 24^{\prime \prime}$ & $116^{\circ} 30^{\prime} 05^{\prime \prime}$ & Snow and Lux (1999), fig. 6; Cemen and others (1999), fig. 9. \\
\hline $\mathrm{O} 30$ & Billie Mine & $36^{\circ} 20^{\prime} 17^{\prime \prime}$ & $116^{\circ} 40^{\prime} 59^{\prime \prime}$ & Wright and others (1999). \\
\hline O31 & Cottonwood Mountains, Section UH1 & $36^{\circ} 57^{\prime} 10^{\prime \prime}$ & $116^{\circ} 26^{\prime} 48^{\prime \prime}$ & Snow and Lux (1999), plate 2. \\
\hline $\mathrm{O} 32$ & Cottonwood Mountains, Section UH2 & $36^{\circ} 57^{\prime} 56^{\prime \prime}$ & $116^{\circ} 24^{\prime} 59^{\prime \prime}$ & Snow and Lux (1999), plate 2. \\
\hline $\mathrm{O} 33$ & Cottonwood Mountains, Section CC1 & $36^{\circ} 35^{\prime} 29^{\prime \prime}$ & $116^{\circ} 16^{\prime} 59^{\prime \prime}$ & Snow and Lux (1999), plate 2. \\
\hline
\end{tabular}


Table 2. Thickness data for lithologic types from measured sections and outcrop descriptions

\begin{tabular}{|c|c|c|c|c|c|c|c|c|}
\hline \multirow{2}{*}{$\begin{array}{l}\text { Location } \\
\text { Number }\end{array}$} & \multirow{2}{*}{$\begin{array}{l}\text { Total exposed } \\
\text { thickness, in } \mathrm{m}\end{array}$} & \multicolumn{4}{|c|}{$\begin{array}{l}\text { Thickness of sedimentary rocks, } \\
\text { in } \mathrm{m}\end{array}$} & \multicolumn{3}{|c|}{$\begin{array}{l}\text { Thickness of volcanic rocks, } \\
\text { in } \mathrm{m}\end{array}$} \\
\hline & & $\begin{array}{l}\text { All sedimentary } \\
\text { rocks }\end{array}$ & $\begin{array}{l}\text { Coarse-grained clastic } \\
\text { rocks }\end{array}$ & $\begin{array}{l}\text { Fine-grained } \\
\text { clastic rocks }\end{array}$ & Limestone & All volcanic rocks & Flows and welded tuff & $\begin{array}{c}\text { Falls and nonwelded } \\
\text { tuff }\end{array}$ \\
\hline $\mathrm{O} 1$ & 925 & 625 & 590 & 23 & 12 & 330 & 0 & 330 \\
\hline $\mathrm{O} 2$ & 295 & 295 & 268 & 27 & 0 & 0 & 0 & 0 \\
\hline $\mathrm{O} 3$ & 295 & 280 & 0 & 0 & 0 & 15 & 0 & 15 \\
\hline O4 & 750 & 550 & 400 & 150 & 0 & 200 & 0 & 200 \\
\hline O5 & 950 & 555 & 220 & 335 & 0 & 395 & 395 & 0 \\
\hline O6 & 1790 & 665 & 380 & 285 & 0 & 1105 & 1105 & 0 \\
\hline O7 & 1700 & 0 & 0 & 0 & 0 & 1700 & 1700 & 0 \\
\hline O8 & 1282 & 1279 & 777 & 282 & 220 & 3 & 0 & 3 \\
\hline O9 & 1780 & 1494 & 386 & 950 & 158 & 286 & 201 & 85 \\
\hline $\mathrm{O} 10$ & 785 & 625 & 395 & 0 & 230 & 160 & 160 & 0 \\
\hline $\mathrm{O} 11$ & 225 & 40 & 40 & 0 & 0 & 185 & 0 & 185 \\
\hline $\mathrm{O} 12$ & 1800 & 1800 & 1800 & 0 & 0 & 0 & 0 & 0 \\
\hline $\mathrm{O} 13$ & 1600 & 1300 & 300 & 0 & 0 & 300 & 0 & 300 \\
\hline O14 & 1800 & 1300 & 1300 & 300 & 0 & 200 & 0 & 200 \\
\hline O15 & 293 & 285 & 49 & 44 & 192 & 8 & 0 & 8 \\
\hline O16 & 1500 & 50 & 30 & 0 & 20 & 1450 & 1450 & 0 \\
\hline O17 & 270 & 270 & 150 & 120 & 0 & 0 & 0 & 0 \\
\hline
\end{tabular}


Table 2. Thickness data for lithologic types from measured sections and outcrop descriptions -- Continued

\begin{tabular}{|c|c|c|c|c|c|c|c|c|}
\hline \multirow{2}{*}{$\begin{array}{l}\text { Location } \\
\text { Number }\end{array}$} & \multirow{2}{*}{$\begin{array}{l}\text { Total exposed } \\
\text { thickness, in } \mathrm{m}\end{array}$} & \multicolumn{4}{|c|}{$\begin{array}{l}\text { Thickness of sedimentary rocks, } \\
\text { in } \mathrm{m}\end{array}$} & \multicolumn{3}{|c|}{$\begin{array}{l}\text { Thickness of volcanic rocks, } \\
\text { in } \mathrm{m}\end{array}$} \\
\hline & & $\begin{array}{l}\text { All sedimentary } \\
\text { rocks }\end{array}$ & $\begin{array}{l}\text { Coarse-grained clastic } \\
\text { rocks }\end{array}$ & $\begin{array}{l}\text { Fine-grained } \\
\text { clastic rocks }\end{array}$ & Limestone & All volcanic rocks & Flows and welded tuff & $\begin{array}{c}\text { Falls and nonwelded } \\
\text { tuff }\end{array}$ \\
\hline $\mathrm{O} 18$ & 450 & 450 & 450 & 0 & 0 & 0 & 0 & 0 \\
\hline O19 & 2200 & 2200 & 2000 & 200 & 0 & 0 & 0 & 0 \\
\hline $\mathrm{O} 20$ & 1000 & 1000 & 900 & 100 & 0 & 0 & 0 & 0 \\
\hline $\mathrm{O} 21$ & 660 & 660 & 460 & 200 & 0 & 0 & 0 & 0 \\
\hline $\mathrm{O} 22$ & 335 & 23 & 0 & 0 & 0 & 312 & 312 & 0 \\
\hline $\mathrm{O} 23$ & 740 & 55 & 0 & 55 & 0 & 685 & 665 & 20 \\
\hline $\mathrm{O} 24$ & 2200 & 0 & 0 & 0 & 0 & 2200 & 2000 & 200 \\
\hline $\mathrm{O} 25$ & 1125 & 60 & 0 & 60 & 0 & 1065 & 1065 & 0 \\
\hline $\mathrm{O} 26$ & 3000 & 2900 & 2000 & 900 & 0 & 100 & 100 & 0 \\
\hline $\mathrm{O} 27$ & 635 & 0 & 0 & 0 & 0 & 635 & 635 & 0 \\
\hline $\mathrm{O} 28$ & 2300 & 2200 & 2200 & 0 & 0 & 100 & 100 & 0 \\
\hline O29 & 595 & 585 & 490 & 0 & 95 & 10 & 0 & 10 \\
\hline $\mathrm{O} 30$ & 1300 & 960 & 910 & 0 & 50 & 340 & 220 & 120 \\
\hline O31 & 635 & 560 & 560 & 0 & 0 & 75 & 75 & 0 \\
\hline O32 & 1010 & 995 & 995 & 0 & 0 & 15 & 15 & 0 \\
\hline $\mathrm{O} 33$ & 392 & 375 & 350 & 15 & 10 & 7 & 7 & 0 \\
\hline
\end{tabular}


Table 3. Location of borehole data used for facies analysis

[Data are compiled from the following sources: USGS - NWIS: U.S. Geological Survey National Water Information System; State of Nevada: State of Nevada, Division of Water Resources, Well Driller's Report; for cited publications, see "References" section of this report]

\begin{tabular}{|c|c|c|c|c|c|c|}
\hline $\begin{array}{l}\text { Location } \\
\text { Number }\end{array}$ & Location Name & Latitude & Lor & gitud & & Data Source \\
\hline B1 & TW- F (1871 ft) & $36^{\circ} 45^{\prime} 34^{\prime \prime}$ & $116^{\circ}$ & 6 & $59 ”$ & USGS - NWIS \\
\hline B2 & TH- 5 & $36^{\circ} 46^{\prime} 1^{\prime \prime}$ & $116^{\circ}$ & $1 '$ & $3 "$ & USGS - NWIS \\
\hline B3 & UE- 5c WW & $36^{\circ} 50^{\prime} 11^{\prime \prime}$ & $115^{\circ}$ & 58 & $47^{\prime \prime}$ & USGS - NWIS \\
\hline B4 & Army 1 WW & $36^{\circ} 35^{\prime} 30^{\prime \prime}$ & $116^{\circ}$ & $2{ }^{\prime}$ & $14 "$ & USGS - NWIS \\
\hline B5 & Army 3 & $36^{\circ} 32^{\prime} 38^{\prime \prime}$ & $115^{\circ}$ & $46^{\prime}$ & $46 "$ & USGS - NWIS \\
\hline B7 & WW- C-1 & $36^{\circ} 55^{\prime} 0^{\prime \prime}$ & $116^{\circ}$ & 0 ' & $39 ”$ & USGS - NWIS \\
\hline B8 & UE- 6d & $36^{\circ} 59^{\prime} 5^{\prime \prime}$ & $116^{\circ}$ & 3 & $32 ”$ & USGS - NWIS \\
\hline B9 & WW- 3 & $36^{\circ} 59^{\prime} 43^{\prime \prime}$ & $116^{\circ}$ & 3 & $29 ”$ & USGS - NWIS \\
\hline B10 & UE- $1 \mathrm{~h}$ & $37^{\circ} 0^{\prime} \quad 5^{\prime \prime}$ & $116^{\circ}$ & $4 '$ & $3 "$ & USGS - NWIS \\
\hline B11 & UE- 1r WW & $37^{\circ} 1 ' \quad 42^{\prime \prime}$ & $116^{\circ}$ & 3 & $33 ”$ & USGS - NWIS \\
\hline B12 & UE- 1d & $37^{\circ} 3{ }^{\prime} \quad 1^{\prime \prime}$ & $116^{\circ}$ & 6 & $53 ”$ & USGS - NWIS \\
\hline B13 & UE- $1 f$ & $37^{\circ} 2^{\prime} \quad 46^{\prime \prime}$ & $116^{\circ}$ & 6 & $49 ”$ & USGS - NWIS \\
\hline B14 & $\mathrm{U}-3$ an 3 & $37^{\circ} 3^{\prime} \quad 54^{\prime \prime}$ & $116^{\circ}$ & $2^{\prime}$ & $14 "$ & USGS - NWIS \\
\hline B15 & TH- 9 & $37^{\circ} 3^{\prime} \quad 11^{\prime \prime}$ & $115^{\circ}$ & $59^{\prime}$ & $18 ”$ & USGS - NWIS \\
\hline B16 & $\mathrm{U}-3 \mathrm{mh}(\mathrm{NT} 1008)$ & $37^{\circ} 1^{\prime} \quad 57^{\prime \prime}$ & $115^{\circ}$ & $59^{\prime}$ & $14 ”$ & USGS - NWIS \\
\hline B17 & UE- 9 ITS US-U-22 & $37^{\circ} 8^{\prime} \quad 7^{\prime \prime}$ & $116^{\circ}$ & 2 & $17 ”$ & USGS - NWIS \\
\hline B18 & U - 2df(NT 604 ) & $37^{\circ} 8, \quad 22^{\prime \prime}$ & $116^{\circ}$ & 5 & $15 "$ & USGS - NWIS \\
\hline B19 & $\mathrm{U}-12 \mathrm{e} .03-1$ & $37^{\circ} 11^{\prime} 22^{\prime \prime}$ & $116^{\circ}$ & 12 & $22 ”$ & USGS - NWIS \\
\hline $\mathrm{B} 20$ & Effinger 4 & $37^{\circ} 10^{\prime} 59^{\prime \prime}$ & $116^{\circ}$ & $10^{\prime}$ & $30 ”$ & USGS - NWIS \\
\hline B21 & Whiterock Springs 3 & $37^{\circ} 11^{\prime} 58^{\prime \prime}$ & $116^{\circ}$ & 7 & $55^{\prime \prime}$ & USGS - NWIS \\
\hline B22 & Whiterock Springs 3A & $37^{\circ} 11^{\prime} 59^{\prime \prime}$ & $116^{\circ}$ & 7 & $52 "$ & USGS - NWIS \\
\hline $\mathrm{B} 23$ & Whiterock Springs 1 & $37^{\circ} 12^{\prime} 4^{\prime \prime}$ & $116^{\circ}$ & 7 & $55^{\prime \prime}$ & USGS - NWIS \\
\hline B24 & USGS Shot Hole & $37^{\circ} 12^{\prime} 5^{\prime \prime}$ & $116^{\circ}$ & $8{ }^{\prime}$ & $2 "$ & USGS - NWIS \\
\hline $\mathrm{B} 25$ & Whiterock Springs 2 & $37^{\circ} 12^{\prime} 10^{\prime \prime}$ & $116^{\circ}$ & 7 & $50 ”$ & USGS - NWIS \\
\hline B26 & Watertown 2 WW & $37^{\circ} 14^{\prime} 39^{\prime \prime}$ & $115^{\circ}$ & 48 & $00 ”$ & USGS - NWIS \\
\hline B27 & Amargosa Farms 45672 & $36^{\circ} 54^{\prime} 8^{\prime \prime}$ & $116^{\circ}$ & $49^{\prime}$ & $1 "$ & State of Nevada \\
\hline B28 & Amargosa Farms 40410 & $36^{\circ} 54^{\prime} 7^{\prime \prime}$ & $116^{\circ}$ & $49^{\prime}$ & $1 "$ & State of Nevada \\
\hline B29 & Amargosa Farms 51620 & $36^{\circ} 54^{\prime} 7^{\prime \prime}$ & $116^{\circ}$ & $48^{\prime}$ & $60 ”$ & State of Nevada \\
\hline
\end{tabular}


Table 3. Location of borehole data used for facies analysis - continued

[Data are compiled from the following sources: USGS - NWIS: U.S. Geological Survey National Water Information System; State of Nevada: State of Nevada, Division of Water Resources, Well Driller's Report; for cited publications, see "References" section of this report]

\begin{tabular}{|c|c|c|c|c|}
\hline $\begin{array}{l}\text { Location } \\
\text { Number } \\
\end{array}$ & Location Name & Latitude & Longitude & Data Source \\
\hline B30 & Amargosa Farms 66226 & $36^{\circ} 53^{\prime} 42^{\prime \prime}$ & $116^{\circ} \quad 49^{\prime} 00^{\prime \prime}$ & State of Nevada \\
\hline B31 & Janet Aubrey & $36^{\circ} 19^{\prime} 49^{\prime \prime}$ & $115^{\circ} 20^{\prime} 18^{\prime \prime}$ & USGS - NWIS \\
\hline B32 & C.R. Coke & $36^{\circ} 19^{\prime} 8^{\prime \prime}$ & $115^{\circ} 16^{\prime} 1^{\prime \prime}$ & USGS - NWIS \\
\hline B33 & Laurence Barringer & $36^{\circ} 16^{\prime} 45^{\prime \prime}$ & $115^{\circ} 16^{\prime} 49^{\prime \prime}$ & USGS - NWIS \\
\hline B34 & Unknown & $36^{\circ} 18^{\prime} 15^{\prime \prime}$ & $115^{\circ} 15^{\prime}, 9^{\prime \prime}$ & USGS - NWIS \\
\hline B35 & Don W. Charleboix & $36^{\circ} 17^{\prime} 32^{\prime \prime}$ & $115^{\circ} 14^{\prime} 21^{\prime \prime}$ & USGS - NWIS \\
\hline B36 & J.J. Fairchild & $36^{\circ} 17^{\prime} 9^{\prime \prime}$ & $115^{\circ} 14^{\prime} 53^{\prime \prime}$ & USGS - NWIS \\
\hline B37 & Leon Bright & $36^{\circ} 16^{\prime} 36^{\prime \prime}$ & $115^{\circ} 15^{\prime} 12^{\prime \prime}$ & USGS - NWIS \\
\hline B38 & H. \& Edna Bierbach & $36^{\circ} 18^{\prime} 16^{\prime \prime}$ & $115^{\circ} 24^{\prime} 13^{\prime \prime}$ & USGS - NWIS \\
\hline B39 & CNLV Leavitt & $36^{\circ} 13^{\prime} 49^{\prime \prime}$ & $115^{\circ} 75^{\prime \prime}$ & USGS - NWIS \\
\hline B40 & UE- $8 \mathrm{e}(2470 \mathrm{ft})$ & $37^{\circ} 10^{\prime} 14^{\prime \prime}$ & $116^{\circ} 5, \quad 16^{\prime \prime}$ & USGS - NWIS \\
\hline B41 & US Borax Exploration SEM-5 & $36^{\circ} 8^{\prime} \quad 53^{\prime \prime}$ & $116^{\circ} 18^{\prime} 41^{\prime \prime}$ & State of Nevada \\
\hline B42 & US Borax Exploration AM-2 & $36^{\circ} 12^{\prime} 1^{\prime \prime}$ & $116^{\circ} 24^{\prime} 14^{\prime \prime}$ & State of Nevada \\
\hline B43 & US Borax Exploration L-3 & $36^{\circ} 14^{\prime} 27^{\prime \prime}$ & $116^{\circ} 29^{\prime} 27^{\prime \prime}$ & State of Nevada \\
\hline B44 & US Borax Exploration S-2 & $36^{\circ} 17^{\prime} 13^{\prime \prime}$ & $116^{\circ} 30^{\prime} 48^{\prime \prime}$ & State of Nevada \\
\hline B45 & US Borax Exploration NA-8 & $36^{\circ} 21^{\prime} 43^{\prime \prime}$ & $116^{\circ} 26^{\prime} 19^{\prime \prime}$ & State of Nevada \\
\hline B46 & US Borax Exploration GS-3 & $36^{\circ} 19^{\prime} 58^{\prime \prime}$ & $116^{\circ} 17^{\prime} 54^{\prime \prime}$ & State of Nevada \\
\hline B47 & $\begin{array}{l}\text { USGS Tracer Study } \\
\text { Exploratory Hole } 3\end{array}$ & $36^{\circ} 32^{\prime} 12^{\prime \prime}$ & $116^{\circ} 13^{\prime} 36^{\prime \prime}$ & Johnston (1968) \\
\hline B48 & $\begin{array}{l}\text { Nye County Land Co. } \\
\text { Amargosa Farms } 9343\end{array}$ & $36^{\circ} 23^{\prime} 48^{\prime \prime}$ & $116^{\circ} 18^{\prime} \quad 12^{\prime \prime}$ & State of Nevada \\
\hline B49 & $\begin{array}{l}\text { Spring Meadows, Inc. } \\
\text { Amargosa Farms } 12942\end{array}$ & $36^{\circ} 27^{\prime} 52^{\prime \prime}$ & $116^{\circ} 20^{\prime} 22^{\prime \prime}$ & State of Nevada \\
\hline B50 & $\begin{array}{l}\text { Nye County Land Co. } \\
\text { Amargosa Farms } 9028\end{array}$ & $36^{\circ} 28^{\prime} 50^{\prime \prime}$ & $116^{\circ} 20^{\prime} 28^{\prime \prime}$ & State of Nevada \\
\hline B51 & $\begin{array}{l}\text { Michael Gilgan Amargosa } \\
\text { Farms } 6943\end{array}$ & $36^{\circ} 28^{\prime} 33^{\prime \prime}$ & $116^{\circ} 26^{\prime} 43^{\prime \prime}$ & State of Nevada \\
\hline B52 & $\begin{array}{l}\text { James E. Owens Amargosa } \\
\text { Farms } 20042\end{array}$ & $36^{\circ} 31^{\prime} 44^{\prime \prime}$ & $116^{\circ} 31^{\prime} 9^{\prime \prime}$ & State of Nevada \\
\hline B53 & US Borax Exploration NT-1 & $36^{\circ} 31^{\prime} 47^{\prime \prime}$ & $116^{\circ} 34^{\prime} 0^{\prime \prime}$ & State of Nevada \\
\hline B54 & Felderhoff Federal 25-1 & $36^{\circ} 35^{\prime} 6^{\prime \prime}$ & $116^{\circ} 23^{\prime} 1^{\prime \prime}$ & Carr and others (1995) \\
\hline
\end{tabular}


Table 3. Location of borehole data used for facies analysis - continued

[Data are compiled from the following sources: USGS - NWIS: U.S. Geological Survey National Water Information System; State of Nevada: State of Nevada, Division of Water Resources, Well Driller's Report; for cited publications, see "References" section of this report]

\begin{tabular}{|c|c|c|c|c|}
\hline $\begin{array}{l}\text { Location } \\
\text { Number }\end{array}$ & Location Name & Latitude & Longitude & Data Source \\
\hline B55 & $\begin{array}{l}\text { Lawrence Funder Amargosa } \\
\text { Farms } 5926\end{array}$ & $36^{\circ} 35^{\prime} 19^{\prime \prime}$ & $116^{\circ} 25^{\prime} 8^{\prime \prime}$ & State of Nevada \\
\hline B56 & $\begin{array}{l}\text { Desert Farms Amargosa Farms } \\
7702\end{array}$ & $36^{\circ} 38^{\prime} 22^{\prime \prime}$ & $116^{\circ} 24^{\prime} 30^{\prime \prime}$ & State of Nevada \\
\hline B57 & US Borax Exploration NA-6 & $36^{\circ} 41^{\prime} 31^{\prime \prime}$ & $116^{\circ} 41^{\prime} 5^{\prime \prime}$ & State of Nevada \\
\hline B58 & NC-EWDP-5S & $36^{\circ} 40^{\prime} 12^{\prime \prime}$ & $116^{\circ} 22^{\prime} 37^{\prime \prime}$ & State of Nevada \\
\hline B59 & NC-EWDP-2D & $36^{\circ} 39^{\prime} 39^{\prime \prime}$ & $116^{\circ} 27^{\prime} 57^{\prime \prime}$ & State of Nevada \\
\hline B60 & NC-EWDP-1S & $36^{\circ} 42^{\prime} 33^{\prime \prime}$ & $116^{\circ} 35^{\prime} 18^{\prime \prime}$ & State of Nevada \\
\hline B61 & $\begin{array}{l}\text { Bond Gold Bullfrog Inc. } \\
\text { BGMW- } 3\end{array}$ & $36^{\circ} 48^{\prime} 53^{\prime \prime}$ & $116^{\circ} 52^{\prime} 8^{\prime \prime}$ & State of Nevada \\
\hline B62 & $\begin{array}{l}\text { Bond Gold Bullfrog Inc. ETW } \\
\text { II- (PW-2) }\end{array}$ & $36^{\circ} 51^{\prime} 10^{\prime \prime}$ & $116^{\circ} 49^{\prime} 30^{\prime \prime}$ & State of Nevada \\
\hline B63 & $\begin{array}{l}\text { Beatty Water District } \\
\text { Amargosa Farms } 52728\end{array}$ & $36^{\circ} 54^{\prime} 49^{\prime \prime}$ & $116^{\circ} 45^{\prime} 13^{\prime \prime}$ & State of Nevada \\
\hline
\end{tabular}


Table 4. Thickness data for lithologic types from boreholes.

\begin{tabular}{|c|c|c|c|c|c|c|c|c|}
\hline \multirow{2}{*}{$\begin{array}{l}\text { Location } \\
\text { Number }\end{array}$} & \multirow{2}{*}{$\begin{array}{l}\text { Total exposed } \\
\text { thickness, in m }\end{array}$} & \multicolumn{4}{|c|}{$\begin{array}{l}\text { Thickness of sedimentary rocks, } \\
\text { in } \mathrm{m}\end{array}$} & \multicolumn{3}{|c|}{$\begin{array}{l}\text { Thickness of volcanic rocks, } \\
\text { in } \mathrm{m}\end{array}$} \\
\hline & & All sedimentary rocks & $\begin{array}{l}\text { Coarse-grained clastic } \\
\text { rocks }\end{array}$ & $\begin{array}{l}\text { Fine-grained } \\
\text { clastic rocks }\end{array}$ & Limestone & $\begin{array}{l}\text { All volcanic } \\
\text { rocks }\end{array}$ & Flows and welded tuff & $\begin{array}{l}\text { Falls and nonwelded } \\
\text { tuff }\end{array}$ \\
\hline $\mathrm{B} 1$ & 436 & 436 & 0 & 436 & 0 & 0 & 0 & 0 \\
\hline B2 & 113 & 0 & 0 & 0 & 0 & 113 & 113 & 0 \\
\hline B3 & 421 & 0 & 0 & 0 & 0 & 421 & 421 & 0 \\
\hline B4 & 76 & 0 & 0 & 0 & 0 & 76 & 76 & 0 \\
\hline B5 & 136 & 0 & 0 & 0 & 0 & 136 & 136 & 0 \\
\hline B6 & 421 & 0 & 0 & 0 & 0 & 421 & 421 & 0 \\
\hline B7 & 332 & 0 & 0 & 0 & 0 & 332 & 0 & 332 \\
\hline B8 & 898 & 872 & 872 & 0 & 0 & 26 & 0 & 26 \\
\hline B9 & 244 & 244 & 244 & 0 & 0 & 0 & 0 & 0 \\
\hline $\mathrm{B} 10$ & 204 & 204 & 204 & 0 & 0 & 0 & 0 & 0 \\
\hline B11 & 3 & 3 & 3 & 0 & 0 & 0 & 0 & 0 \\
\hline B12 & 67 & 0 & 0 & 0 & 0 & 67 & 0 & 67 \\
\hline B13 & 73 & 52 & 52 & 0 & 0 & 21 & 21 & 0 \\
\hline B14 & 509 & 0 & 0 & 0 & 0 & 509 & 509 & 0 \\
\hline B15 & 311 & 0 & 0 & 0 & 0 & 311 & 0 & 311 \\
\hline B16 & 20 & 20 & 20 & 0 & 0 & 0 & 0 & 0 \\
\hline B17 & 358 & 0 & 0 & 0 & 0 & 358 & 358 & 0 \\
\hline B18 & 2 & 0 & 0 & 0 & 0 & 2 & 2 & 0 \\
\hline B19 & 220 & 0 & 0 & 0 & 0 & 220 & 220 & 0 \\
\hline B20 & 3 & 0 & 0 & 0 & 0 & 3 & 3 & 0 \\
\hline B21 & 13 & 0 & 0 & 0 & 0 & 13 & 13 & 0 \\
\hline B22 & 3 & 0 & 0 & 0 & 0 & 3 & 3 & 0 \\
\hline B23 & 22 & 0 & 0 & 0 & 0 & 22 & 22 & 0 \\
\hline B24 & 32 & 0 & 0 & 0 & 0 & 32 & 32 & 0 \\
\hline B25 & 26 & 0 & 0 & 0 & 0 & 26 & 26 & 0 \\
\hline B26 & 187 & 0 & 0 & 0 & 0 & 187 & 187 & 0 \\
\hline $\mathrm{B} 27$ & 393 & 0 & 0 & 0 & 0 & 393 & 393 & 0 \\
\hline
\end{tabular}


Table 4. Thickness data for lithologic types from boreholes -- Continued.

\begin{tabular}{|c|c|c|c|c|c|c|c|c|}
\hline \multirow{2}{*}{$\begin{array}{l}\text { Location } \\
\text { Number }\end{array}$} & \multirow{2}{*}{$\begin{array}{l}\text { Total exposed } \\
\text { thickness, in } \mathrm{m}\end{array}$} & \multicolumn{4}{|c|}{$\begin{array}{l}\text { Thickness of sedimentary rocks, } \\
\text { in } \mathrm{m}\end{array}$} & \multicolumn{3}{|c|}{$\begin{array}{l}\text { Thickness of volcanic rocks, } \\
\text { in } \mathrm{m}\end{array}$} \\
\hline & & All sedimentary rocks & $\begin{array}{l}\text { Coarse-grained clastic } \\
\text { rocks }\end{array}$ & $\begin{array}{l}\text { Fine-grained } \\
\text { clastic rocks }\end{array}$ & Limestone & $\begin{array}{l}\text { All volcanic } \\
\text { rocks }\end{array}$ & Flows and welded tuff & $\begin{array}{l}\text { Falls and nonwelded } \\
\text { tuff }\end{array}$ \\
\hline $\mathrm{B} 28$ & 183 & 0 & 0 & 0 & 0 & 183 & 183 & 0 \\
\hline B29 & 95 & 0 & 0 & 0 & 0 & 95 & 94 & 1 \\
\hline B30 & 346 & 6 & 0 & 6 & 0 & 340 & 340 & 0 \\
\hline B31 & 166 & 166 & 166 & 0 & 0 & 0 & 0 & 0 \\
\hline B32 & 104 & 104 & 0 & 104 & 0 & 0 & 0 & 0 \\
\hline B33 & 47 & 47 & 7 & 40 & 0 & 0 & 0 & 0 \\
\hline B34 & 51 & 51 & 0 & 51 & 0 & 0 & 0 & 0 \\
\hline B35 & 69 & 69 & 18 & 51 & 0 & 0 & 0 & 0 \\
\hline B36 & 145 & 145 & 120 & 25 & 0 & 0 & 0 & 0 \\
\hline B37 & 30 & 30 & 8 & 22 & 0 & 0 & 0 & 0 \\
\hline B38 & 52 & 52 & 52 & 0 & 0 & 0 & 0 & 0 \\
\hline B39 & 304 & 304 & 6 & 298 & 0 & 0 & 0 & 0 \\
\hline B40 & 37 & 16 & 0 & 16 & 0 & 21 & 0 & 21 \\
\hline B41 & 263 & 252 & 252 & 0 & 0 & 11 & 5 & 6 \\
\hline B42 & 390 & 255 & 29 & 226 & 0 & 135 & 135 & 0 \\
\hline B43 & 563 & 450 & 224 & 192 & 34 & 113 & 42 & 71 \\
\hline B44 & 534 & 515 & 169 & 346 & 0 & 19 & 19 & 0 \\
\hline B45 & 583 & 583 & 375 & 208 & 0 & 0 & 0 & 0 \\
\hline B46 & 604 & 604 & 0 & 604 & 0 & 0 & 0 & 0 \\
\hline B47 & 92 & 90 & 90 & 0 & 0 & 2 & 2 & 0 \\
\hline B48 & 179 & 179 & 52 & 84 & 43 & 0 & 0 & 0 \\
\hline B49 & 248 & 248 & 0 & 154 & 94 & 0 & 0 & 0 \\
\hline B50 & 179 & 179 & 9 & 114 & 56 & 0 & 0 & 0 \\
\hline B51 & 90 & 90 & 0 & 90 & 0 & 0 & 0 & 0 \\
\hline B52 & 124 & 124 & 100 & 24 & 0 & 0 & 0 & 0 \\
\hline B53 & 468 & 300 & 234 & 0 & 66 & 168 & 168 & 0 \\
\hline B54 & 529 & 370 & 361 & 0 & 9 & 159 & 159 & 0 \\
\hline
\end{tabular}


Table 4. Thickness data for lithologic types from boreholes - Continued.

\begin{tabular}{|c|c|c|c|c|c|c|c|c|}
\hline \multirow{2}{*}{$\begin{array}{l}\text { Location } \\
\text { Number }\end{array}$} & \multirow{2}{*}{$\begin{array}{l}\text { Total exposed } \\
\text { thickness, in } \mathrm{m}\end{array}$} & \multicolumn{4}{|c|}{$\begin{array}{l}\text { Thickness of sedimentary rocks, } \\
\text { in } \mathrm{m}\end{array}$} & \multicolumn{3}{|c|}{$\begin{array}{l}\text { Thickness of volcanic rocks, } \\
\text { in } \mathrm{m}\end{array}$} \\
\hline & & All sedimentary rocks & $\begin{array}{l}\text { Coarse-grained clastic } \\
\text { rocks }\end{array}$ & $\begin{array}{l}\text { Fine-grained } \\
\text { clastic rocks }\end{array}$ & Limestone & $\begin{array}{l}\text { All volcanic } \\
\text { rocks }\end{array}$ & Flows and welded tuff & $\begin{array}{c}\text { Falls and nonwelded } \\
\text { tuff }\end{array}$ \\
\hline $\bar{B} 55$ & 175 & 175 & 23 & 140 & 12 & 0 & 0 & 0 \\
\hline B56 & 187 & 187 & 107 & 80 & 0 & 0 & 0 & 0 \\
\hline B57 & 170 & 54 & 54 & 0 & 0 & 116 & 116 & 0 \\
\hline B58 & 278 & 251 & 101 & 50 & 0 & 27 & 0 & 27 \\
\hline B59 & 142 & 112 & 112 & 0 & 0 & 30 & 0 & 30 \\
\hline $\mathrm{B} 60$ & 715 & 590 & 337 & 253 & 0 & 125 & 78 & 47 \\
\hline B61 & 103 & 103 & 103 & 0 & 0 & 0 & 0 & 0 \\
\hline B62 & 172 & 172 & 172 & 0 & 0 & 0 & 0 & 0 \\
\hline B63 & 151 & 123 & 95 & 0 & 28 & 28 & 28 & 0 \\
\hline B64 & 427 & 0 & 0 & 0 & 0 & 427 & 427 & 0 \\
\hline
\end{tabular}




\section{Tertiary Thickness Modeled from Gravity Data}

Inverse modeling of gravity data from the region (fig. 4) has greatly contributed to the knowledge of the Tertiary tectonic style and the subsurface configuration of the Tertiary basins (Blakely and others, 1999). Such models can be used to estimate the thickness of Tertiary basin fill, but with some caveats. The model estimates the thickness of Cenozoic deposits based on a computational inversion (Jachens and Moring, 1990) of gravity data (Saltus and Jachens, 1995; Blakely and others, 1998; Blakely and others, 1999) combined with density-depth assumptions. The models separate the pre-Cenozoic "basement" from the entire Cenozoic basin fill, including Tertiary and Quaternary sedimentary and volcanic rocks. In areas that are far from volcanic sources, such as the Pahrump Valley, portions of the Amargosa Valley and the Las Vegas Valley, the modeled thickness may approximate the thickness of the Tertiary basin-filling rocks. However, the gravity models do not separate out volcanic rocks where they are thick enough to be assigned their own hydrogeologic unit. Thus, the thickness of the Tertiary section as described by the gravity model is not indicative of the thickness of the undifferentiated Tertiary basin-filling rocks when close to volcanic fields. 


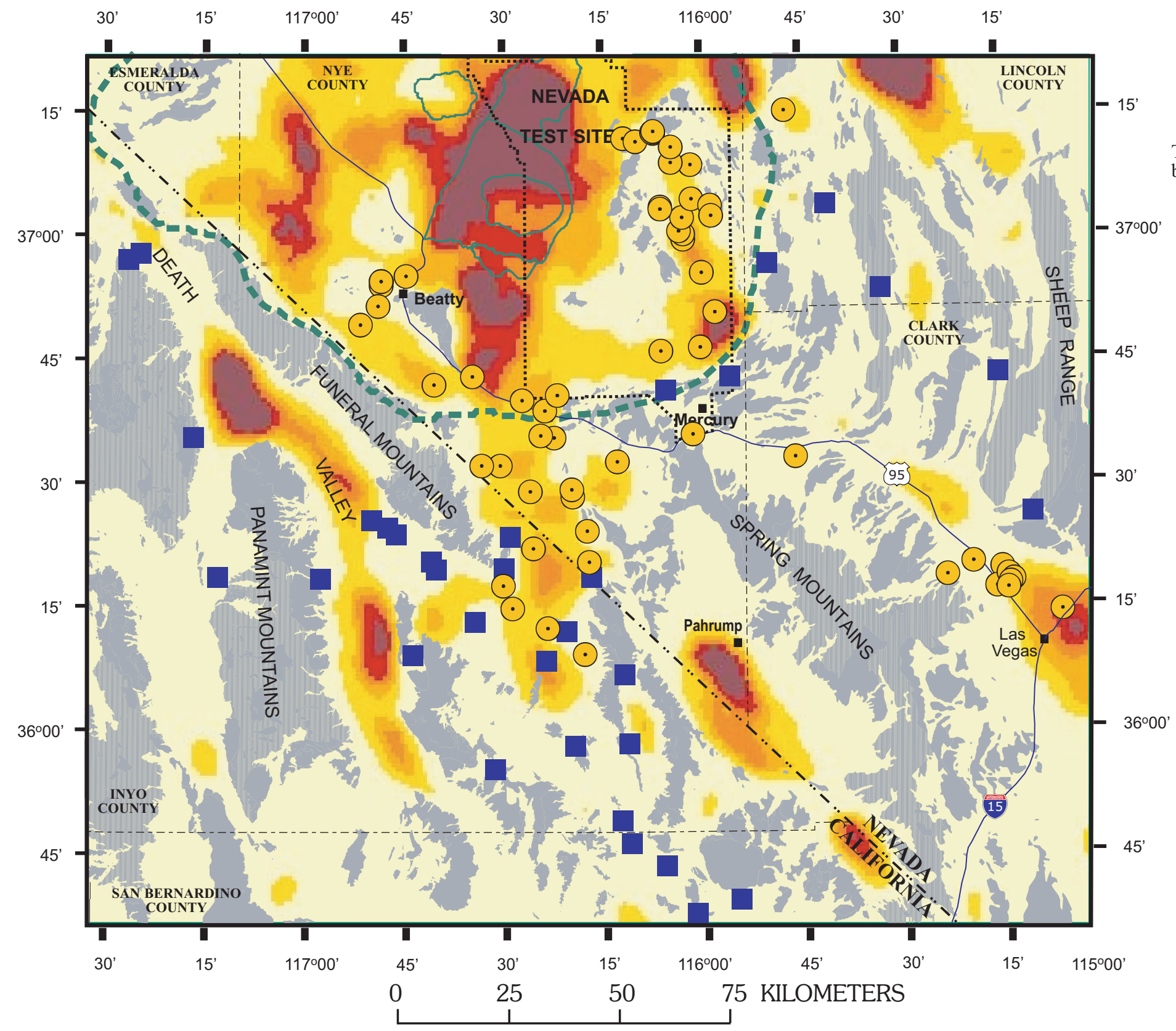

\section{EXPLANATION}

Outcrop of pre-Cenozoic rocks

Thickness of Tertiary basin-filling rocks, based on gravity model of Blakely (1999).

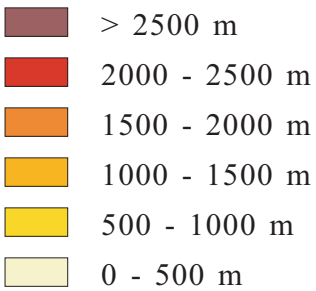

- Location of outcrop observation or measured section

- Location of borehole

Caldera boundary Approximate limit of southwestern Nevada volcanic field

- ..... State boundary

- - - - County boundary Nevada Test Site boundary

-15- Interstate Highway

95 - State Highway

Figure 4. Thickness of Cenozoic basin fill based on gravity model. 


\section{Regional Facies Trends}

\section{Thickness}

Thickness of undifferentiated Tertiary basin fill as measured from boreholes and outcrop is skewed toward outcrop data (fig. 5); most of the boreholes are shallow and underestimate the total thickness of the unit. The contoured data show bull's eye type trends due to sparse data coverage.

Thickness estimated from an inversion of the gravity data (Blakely and others, 1998; 1999) (fig. 4) better delineates the Tertiary basins, but includes all Cenozoic rocks. In areas that are far from volcanic sources, the modeled thickness may approximate the thickness of the Tertiary basin-filling rocks. Modeling of regional gravity data has revealed the presence of a number of deep troughs that are likely to be filled with Tertiary sedimentary rock (Blakely and others, 1999). Gravity modeling of the Stewart ValleyPahrump strike-slip fault zone (roughly parallel to the California-Nevada boundary on figure 5) shows that the fault is associated with complex variations in the elevation of the Tertiary-Paleozoic contact (Blakely and others, 1998). In the Pahrump Valley, the Stewart Valley-Pahrump fault zone forms a buried transpressional bedrock ridge separating two steep-sided, probably fault-bounded Tertiary basins (Blakely and others, 1998). The basins are interpreted to be transtensional basins associated with right steps in this fault system (Wright, 1989; Blakely and others, 1998). To the northwest in the Amargosa Valley, this fault zone forms another northwest trending bedrock ridge that separates two northwest trending basins (Blakely and others, 1999). Modeling of regional gravity data from Death Valley reveals a number of narrow, step-sided, sediment-filled troughs (Blakely and others, 1999).

\section{Compositional Trends}

Figures 6 and 7 show the distribution of sedimentary and volcanic portions of the Tertiary basin fill, respectively. Depocenters for Tertiary sedimentary rocks include coarse conglomerates in the Kingston Wash area (southern edge of fig. 6) and the Nova basin to the west of the Panamint Mountains, as well as more localized sedimentary successions in Furnace Creek Wash, in the southern part of the Nevada Test Site, and in 


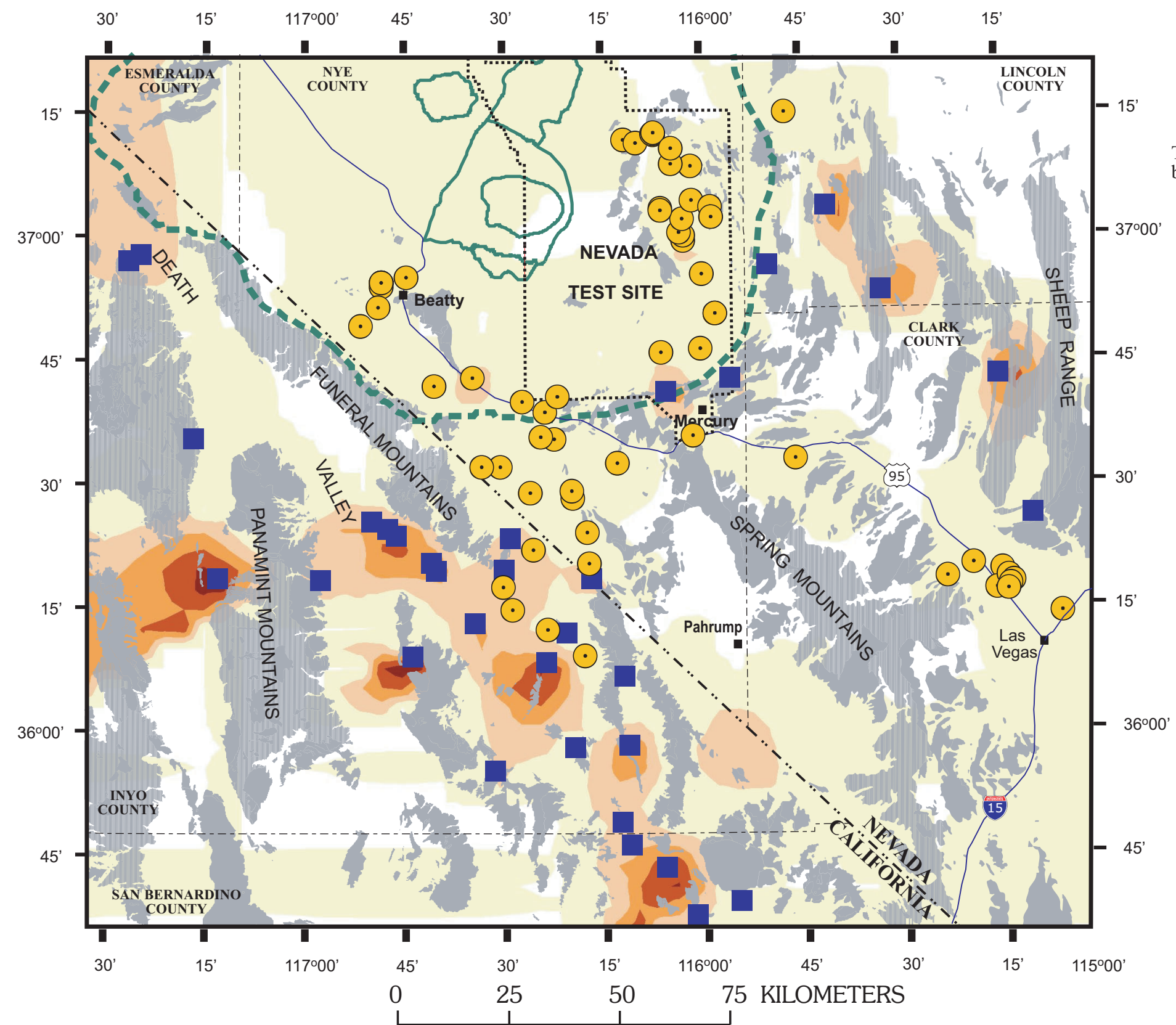

\section{EXPLANATION}

Outcrop of pre-Cenozoic rocks

Thickness of Tertiary basin-filling rocks, based on outcrop and borehole data

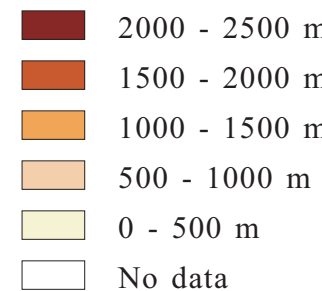

Location of outcrop observation

- Location of borehole

\section{Caldera boundary}

Approximate limit of southwestern Nevada volcanic field

_..... State boundary

- _ - County boundary

Nevada Test Site boundary

-15- Interstate Highway

$-\widetilde{95}$ - State Highway

Figure 5. Thickness of undifferentiated Tertiary basin fill based on measurements in outcrop and in boreholes. 


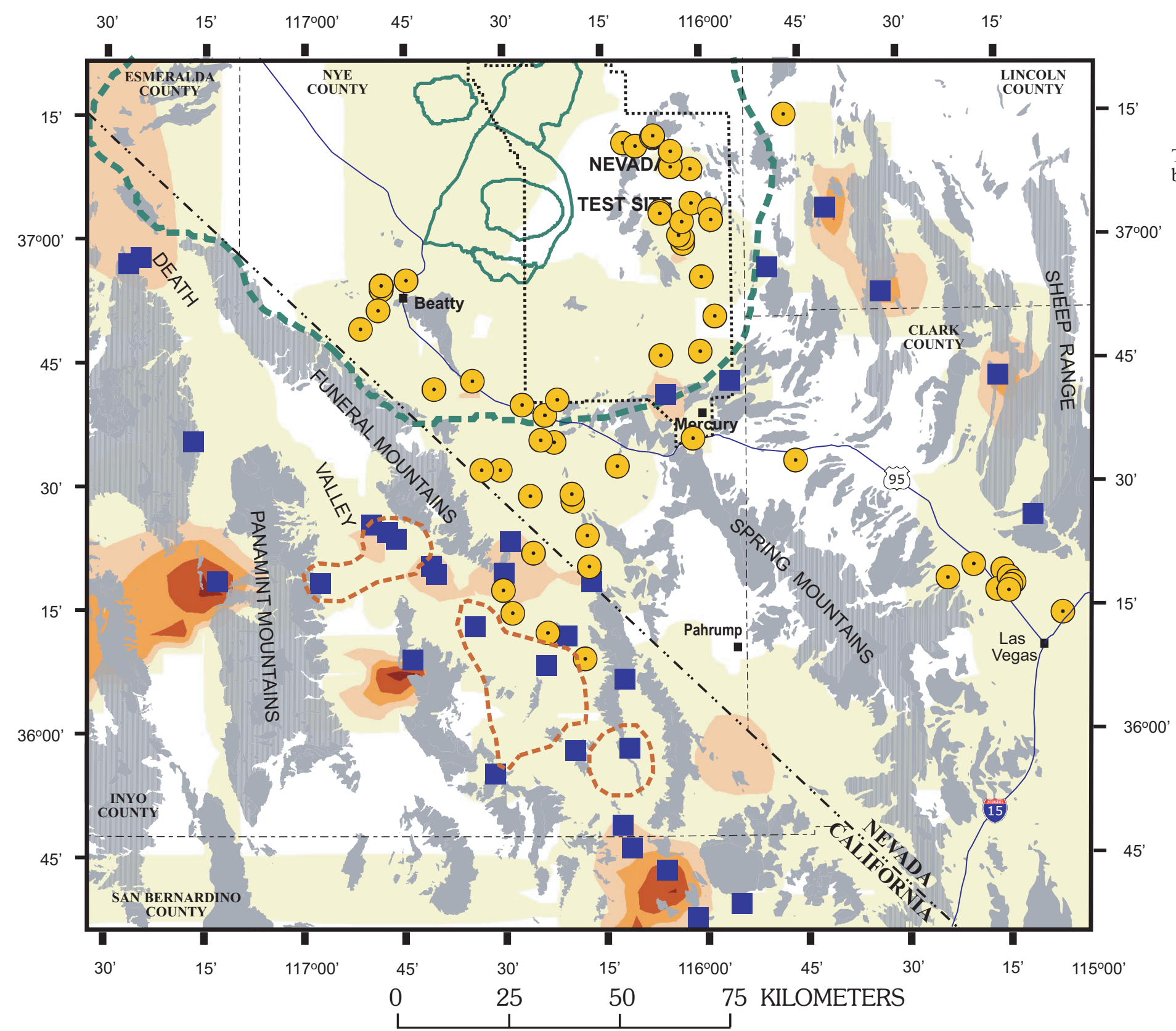

Figure 6. Thickness of Tertiary sedimentary rocks based on measurements at outcrops and in boreholes.

\section{EXPLANATION}

Outcrop of pre-Cenozoic rocks

Thickness of Tertiary sedimentary rocks, based on outcrop and borehole data

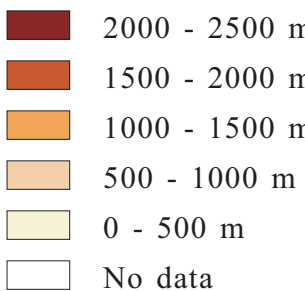

Areas of thickest undifferentiated Tertiary volcanic rocks (see fig. 7)

Location of outcrop observation or measured section

$\odot$ Location of borehole

Caldera boundary Approximate limit of southwestern Nevada volcanic field

$\ldots \ldots$ State boundary

- _ - County boundary Nevada Test Site boundary

-15- Interstate Highway

-25 - State Highway 


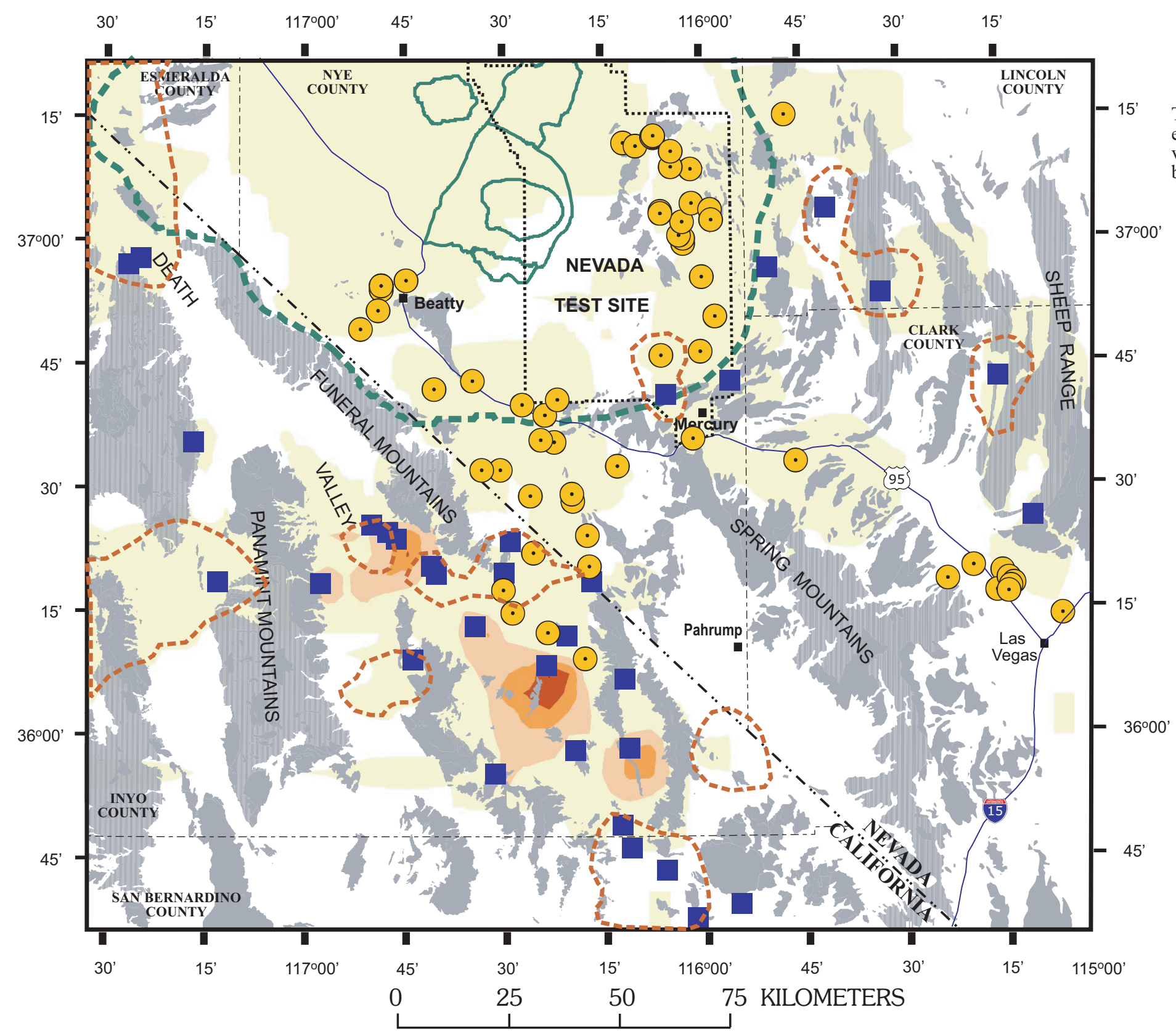

Figure 7. Thickness of Tertiary volcanic rocks outside the southwestern Nevada volcanic field.

\section{EXPLANATION}

Outcrop of pre-Cenozoic rocks

Thickness of Tertiary volcanic rocks, xclusive of the southwestern Nevada volcanic field, based on outcrop and borehole data

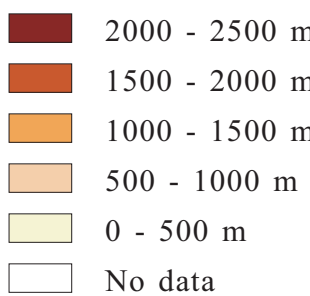

Areas of thickes undifferentiated Tertiary sedimentary rocks (see fig. 6)

Location of outcrop observation or measured section

$\odot$ Location of borehole

Caldera boundary Approximate limit of southwestern Nevada volcanic field

..... State boundary

- - - County boundary Nevada Test Site boundary

-15- Interstate Highway

-25 - State Highway 
Lincoln County. The extent of sediments under the volcanic pile of the southwestern Nevada volcanic field is largely unknown. Shallow boreholes in the northwest part of the Las Vegas Valley do not penetrate the thick Tertiary section in the center of the valley (Longwell and others, 1965; Plume, 1989). The extensive Tertiary sedimentary rocks that underlie Death Valley are here represented by a single outcrop data point - the uplifted Copper Canyon basin.

Tertiary volcanic rocks exclusive of the named volcanic rocks from the southwestern Nevada volcanic field are primarily aligned along a northwest-southeast trend (fig. 7) that is associated with the Furnace Creek fault and the central Death Valley volcanic-plutonic province. Tertiary sedimentary and volcanic rocks occupy different depocenters; primarily the result of the sweep of tectonism and volcanism across this region that results in spatially variable and shifting locus of deposition through time.

The distribution of Tertiary limestone (fig. 8) varies both spatially and stratigraphically throughout the region. North of Las Vegas and to the north and west of Mercury, the thickest Tertiary limestones are present in the lower to middle Miocene rocks that are equivalent to the "rocks of Pavits Spring" on the Nevada Test Site. Late Oligocene to Early Miocene limestones are exposed at Bat Mountain (Cemen and others, 1999). In the central Amargosa Valley, a shallow Tertiary limestone of unknown but probably younger age is present in many of the boreholes in the Amargosa Farms area.

Tertiary basins dominated by sedimentary rocks (fig. 9) include the Amargosa Desert, the Las Vegas Valley, the Pahrump Valley and the Shadow Valley basin/Kingston Wash/China Ranch area. Death Valley and the northern half of the Pahrump Valley are not well represented due to lack of data. A breakdown of coarse-grained (sand-sized and larger) versus fine-grained (smaller than sand) sedimentary rocks is also shown on figure 9. Grain size information is variable in quality and depends on the detail present in published descriptions. There are some bull's-eyes based on limited, isolated data, but some trends are recognizable as well. The transition from coarse-grained to fine-grained sedimentary rocks in the northwest edge of the Las Vegas Valley, previously documented by Plume (1989) is evident here. The coarse synextensional gravels and megabreccias in the Kingston Wash area are also evident. The Amargosa Desert shows a complex pattern 


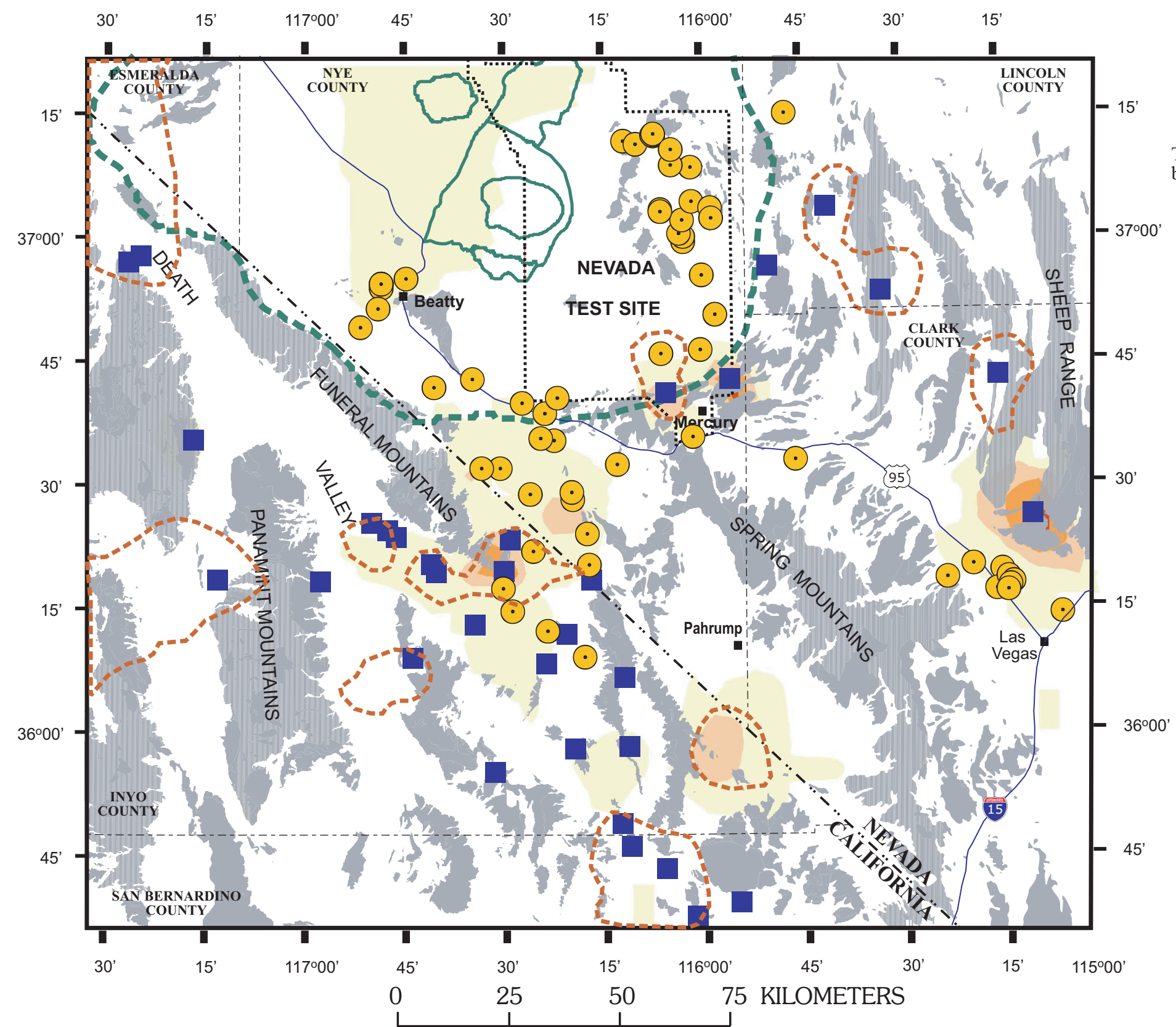

\section{EXPLANATION}

Outcrop of pre-Cenozoic rocks

Thickness of Tertiary basin-filling rocks, based on outcrop and borehole data

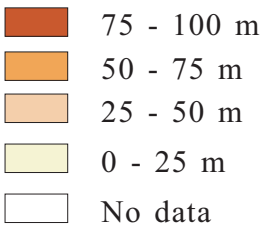

\section{Areas of thickest undifferentiated Tertiary sedimentary rocks (see fig. 6)}

Location of outcrop observation or measured section

- Location of borehole

Caldera boundary Approximate limit of southwestern Nevada volcanic field

$\ldots$ _... State boundary

- _ - County boundary Nevada Test Site boundary

-15- Interstate Highway

$-\widetilde{95}$ - State Highway

Figure 8. Thickness of Tertiary limestones based on measurements at outcrops and in boreholes. 


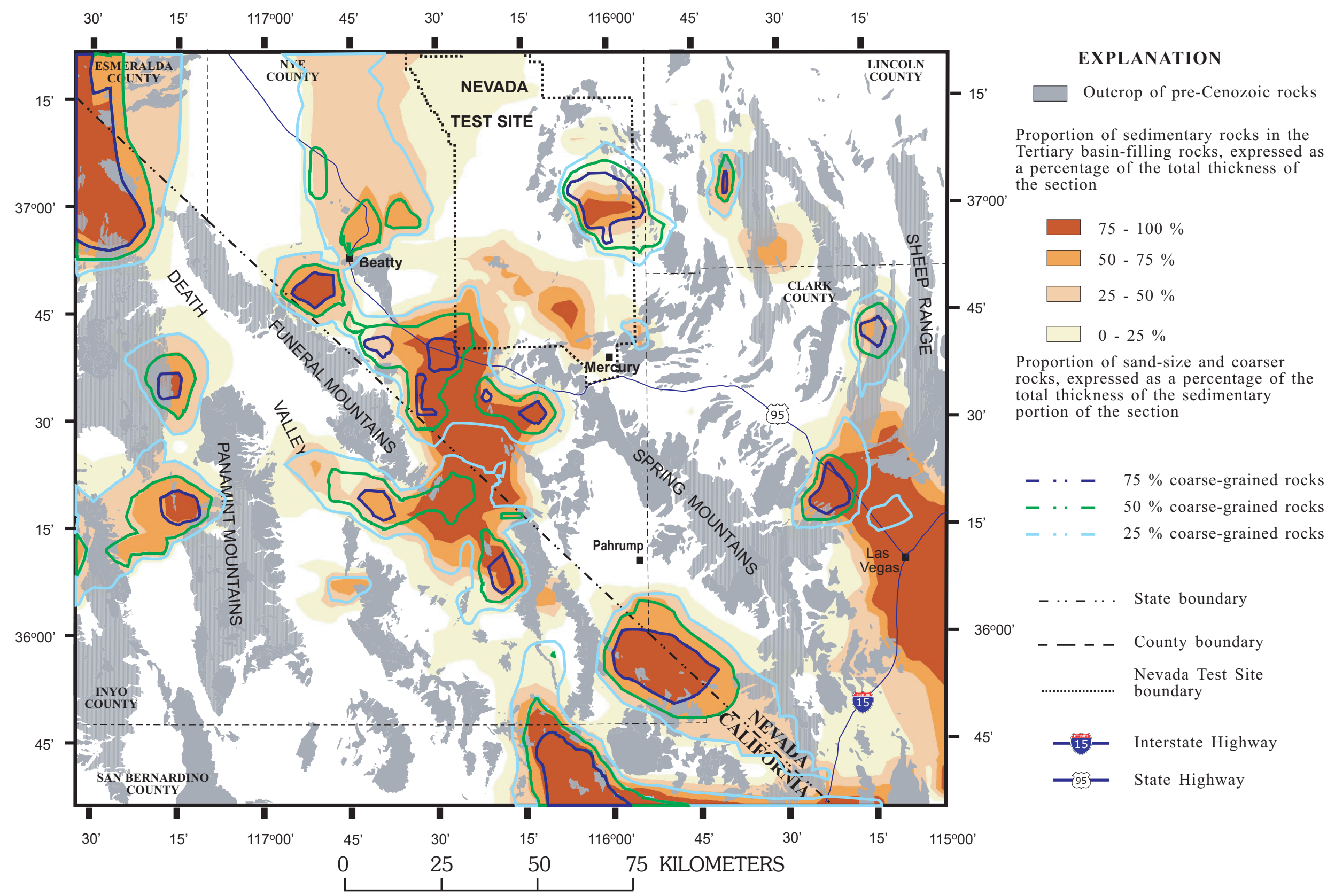

Figure 9. Relative proportion of sedimentary rocks in the Tertiary section and grain size characteristics. 
of grain size distribution, in part reflecting the presence of fine-grained sediments in the basin center.

Tertiary basins dominated by volcanic rocks (fig. 10) include the margins of the southwestern Nevada volcanic field and the central Death Valley volcanic-plutonic province. Thick sequences of regionally extensive ash-flow tuffs derived from the southwestern Nevada volcanic field known to be present beneath Yucca Flat, Crater Flat and at Yucca Mountain are not shown on figure 10. These volcanic units are thick enough and well enough known to be modeled as their own hydrogeologic units, rather than being lumped with coeval Tertiary sediments. When rhyolite and basalt lava flows and ash-flow tuffs are separated from airfall tuff and ash deposits (contours on figure 10), the thick accumulations of volcanic rocks are seen to be dominated by the tuffs and lava flows, as expected proximal to volcanic source areas. Thinner, distal sections are dominated by airfall material, such as in the Ash Meadows area of the Amargosa Desert.

\section{Amargosa Desert Borehole Data}

A preliminary compilation of data from 188 boreholes in the Amargosa Desert compliments surface and subsurface geologic investigations conducted in the area at the regional scale $(1: 250,000)$. Borehole data are being used to identify Quaternary and Tertiary volcanic and sedimentary rocks within the basin, classify them into hydrogeologic units, and map the subsurface distribution of these units. The principal hydrogeologic units that can be recognized and correlated in the Amargosa Desert are:

- Fine-grained alluvium including playa deposits and basin-axis mudstone;

- Quaternary and Tertiary coarse-grained alluvium (sand and gravel) including near surface unconsolidated gravels and sands and late-stage basin fill;

- Quaternary-Tertiary spring/lacustrine deposits including an upper limestone aquifer; 


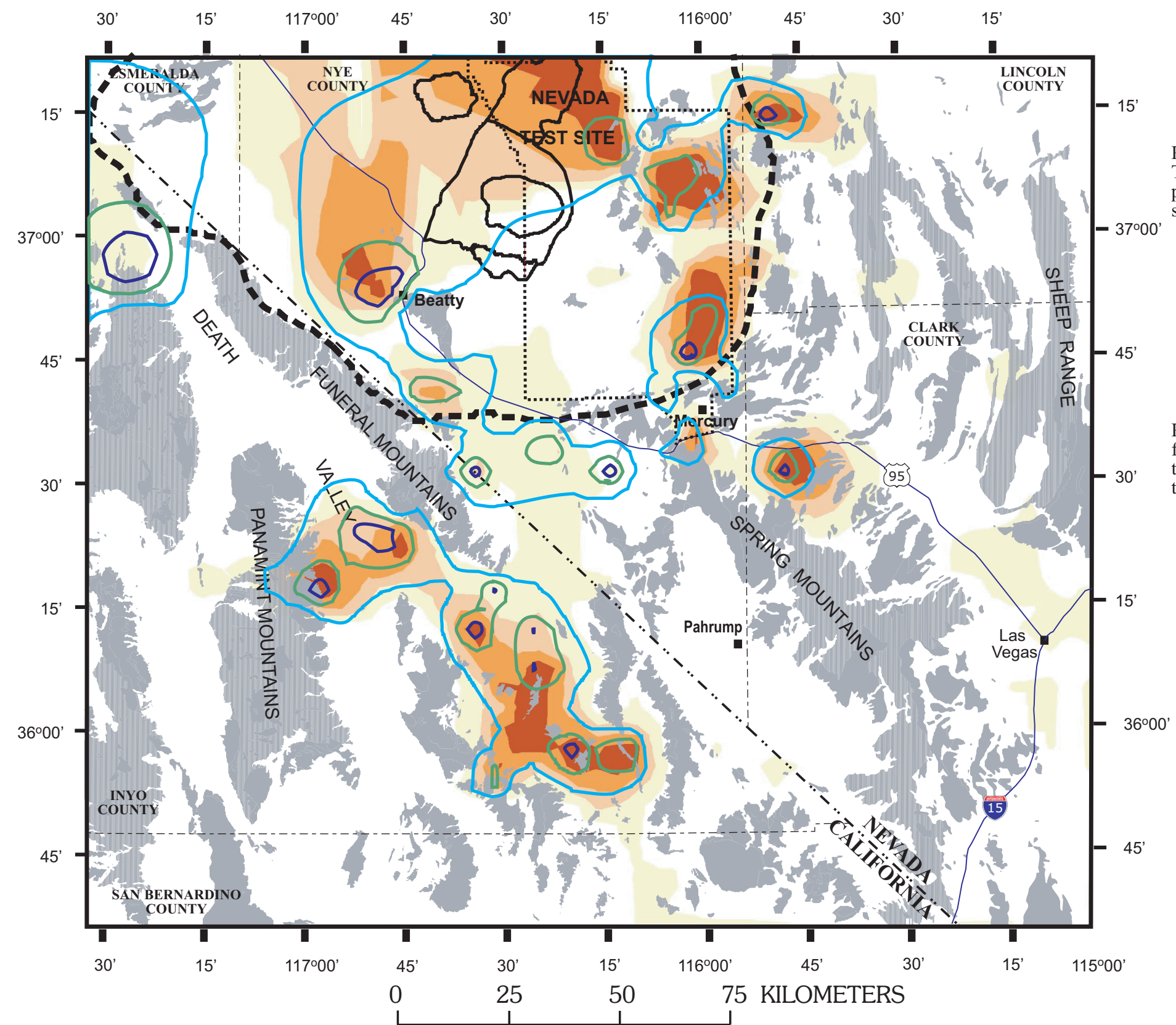

\section{EXPLANATION}

Outcrop of pre-Cenozoic rocks

Proportion of volcanic rocks in the Tertiary basin-filling rocks, expressed as a percentage of the total thickness of the section

$$
\begin{aligned}
& 75-100 \% \\
& 50-75 \% \\
& \text { ? } 25-50 \% \\
& \square-25 \%
\end{aligned}
$$

Proportion of rocks that are tuffs and lava flows, expressed as a percentage of the total thickness of the volcanic portion of the section

$$
\begin{aligned}
& \text { - . - } \quad 75 \% \text { flows } \\
& \text { — - - } 50 \% \text { flows } \\
& \text { - . - } 25 \% \text { flows } \\
& \text { Caldera boundary } \\
& \text { Approximate limit of } \\
& \text { southwestern Nevada } \\
& \text { volcanic field } \\
& \text { - ..... State boundary } \\
& \text { - _ - C County boundary } \\
& \text { Nevada Test Site } \\
& \text { boundary }
\end{aligned}
$$

Figure 10. Relative proportion of volcanic rocks in the Tertiary section and rock type. 
- Basalt;

- Silicic volcanic welded tuffs, subdivided when adequate data are available;

- A consolidated (mostly Tertiary) mixed unit of clastic and volcaniclastic rocks.

A principal difficulty in the initial compilation and stratigraphic analyses of borehole data from the Amargosa Desert involved integrating subsurface lithologic data known to be of high quality, such as those data from the Nye County Early Warning Drilling Program (EWDP) boreholes to the south of Yucca Mountain and the Felderhoff boreholes (Carr and others, 1995) with information contained in driller's logs that are source of data for many of the holes in the Amargosa Farms area (Oatfield and Czarnecki, 1989). Many of the boreholes in the area (fig. 11) are shallow; deeper boreholes provide important control points. Subsurface geologic units are defined in generalized lithologic terms, based on characteristics of hydrogeologic importance such as permeability and are compared where possible to existing surficial maps to define the spatial extents of the major lithologic units, including alluvial channels, spring deposits, outcrops of freshwater limestones, basin center and playa deposits, and transitions from coarse-grained to fine-grained clastic sedimentary deposits.

Two preliminary stratigraphic sections across the Amargosa Desert (figs. 12 and 13) display some of the stratigraphic complexity and facies trends within the basin. The east-west section (fig. 12) highlights the segmented nature of the basin: a relatively thick section of Tertiary volcanic rocks along the northeastern flank of the Funeral Mountains gives way to sections that are dominated by shallow Tertiary limestones in the Amargosa Farms area. Boreholes on the eastern end of the section penetrate local basalt flows. Many of the boreholes at the northern end of the north-south cross section (fig. 13) penetrate volcanic rocks associated with the southwestern Nevada volcanic field. These volcanic rocks are absent beyond the central part of the section, giving way again to the shallow Tertiary limestones in the Amargosa Farms area, thicker limestone-poor sections to the south, and at the southern end, a section that contains volcanic rocks associated with the central Death Valley volcanic field. 


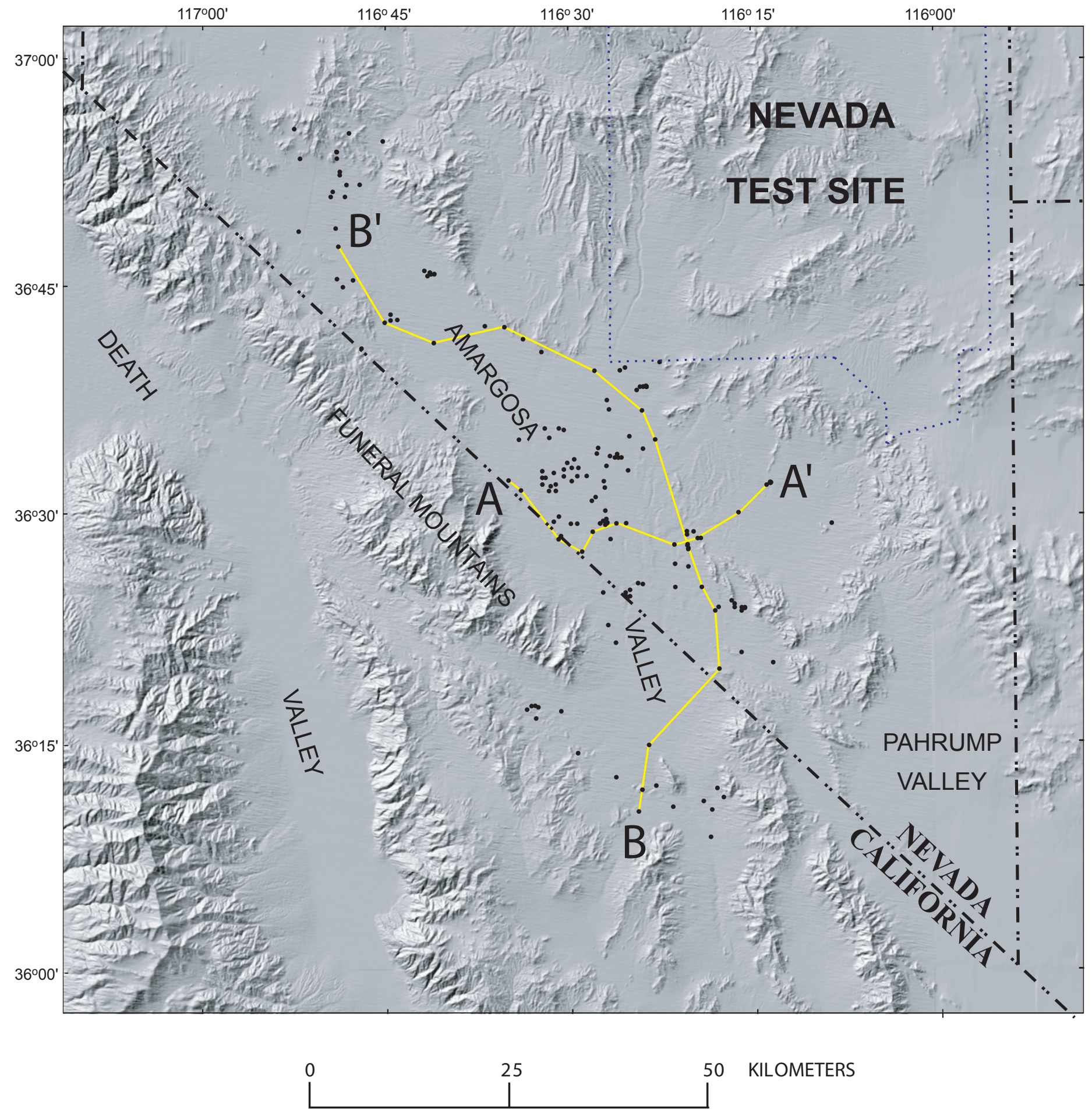

Figure 11. Location map of boreholes and stratigraphic cross sections in the vicinity of the Amargosa Desert. 
A

$A^{\prime}$

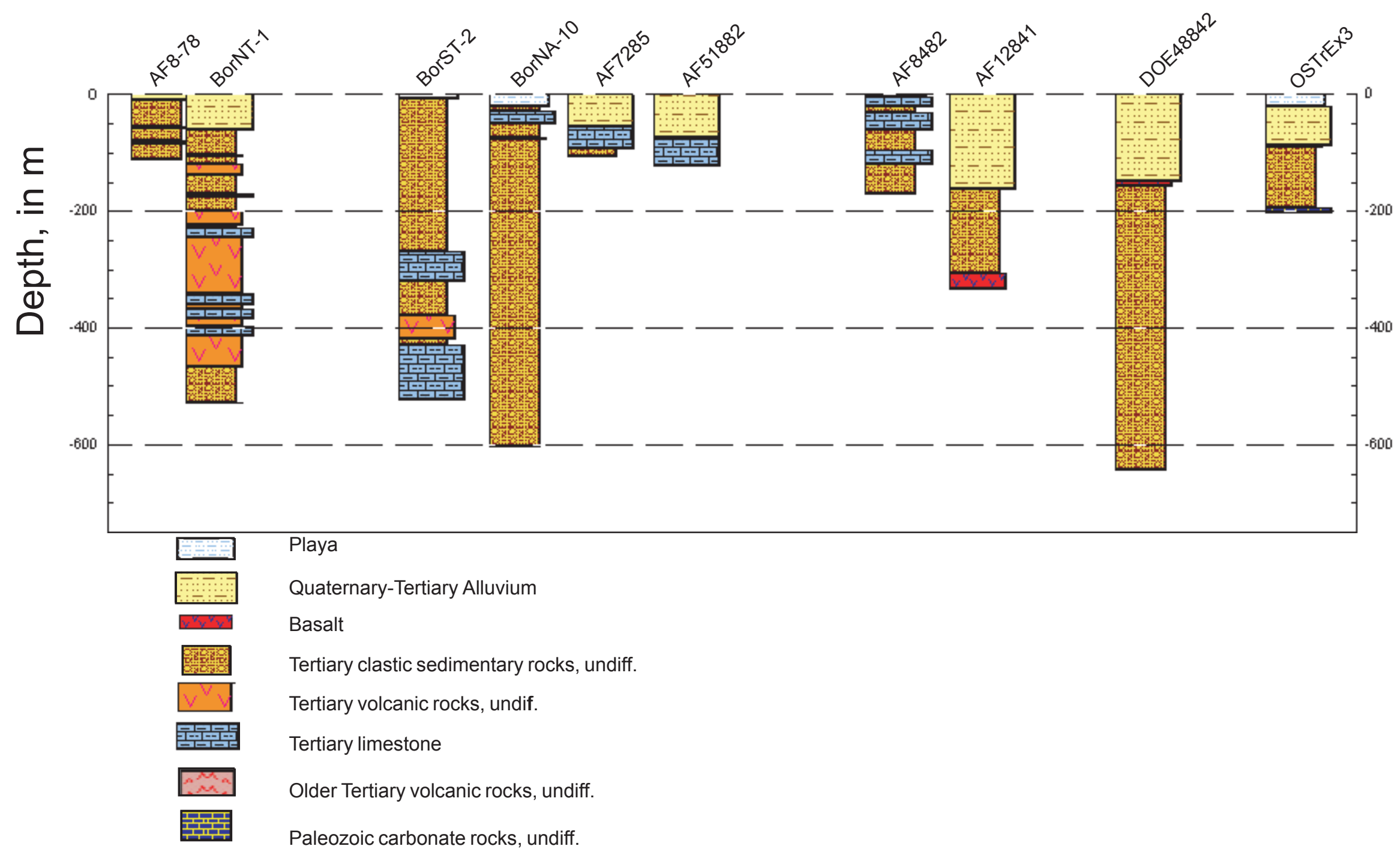

Figure 12. Stratigraphic cross section A-A'. Section is oriented approximately east-west through the central portion of the Amargosa Desert. See fig. 11 for section line. 
B

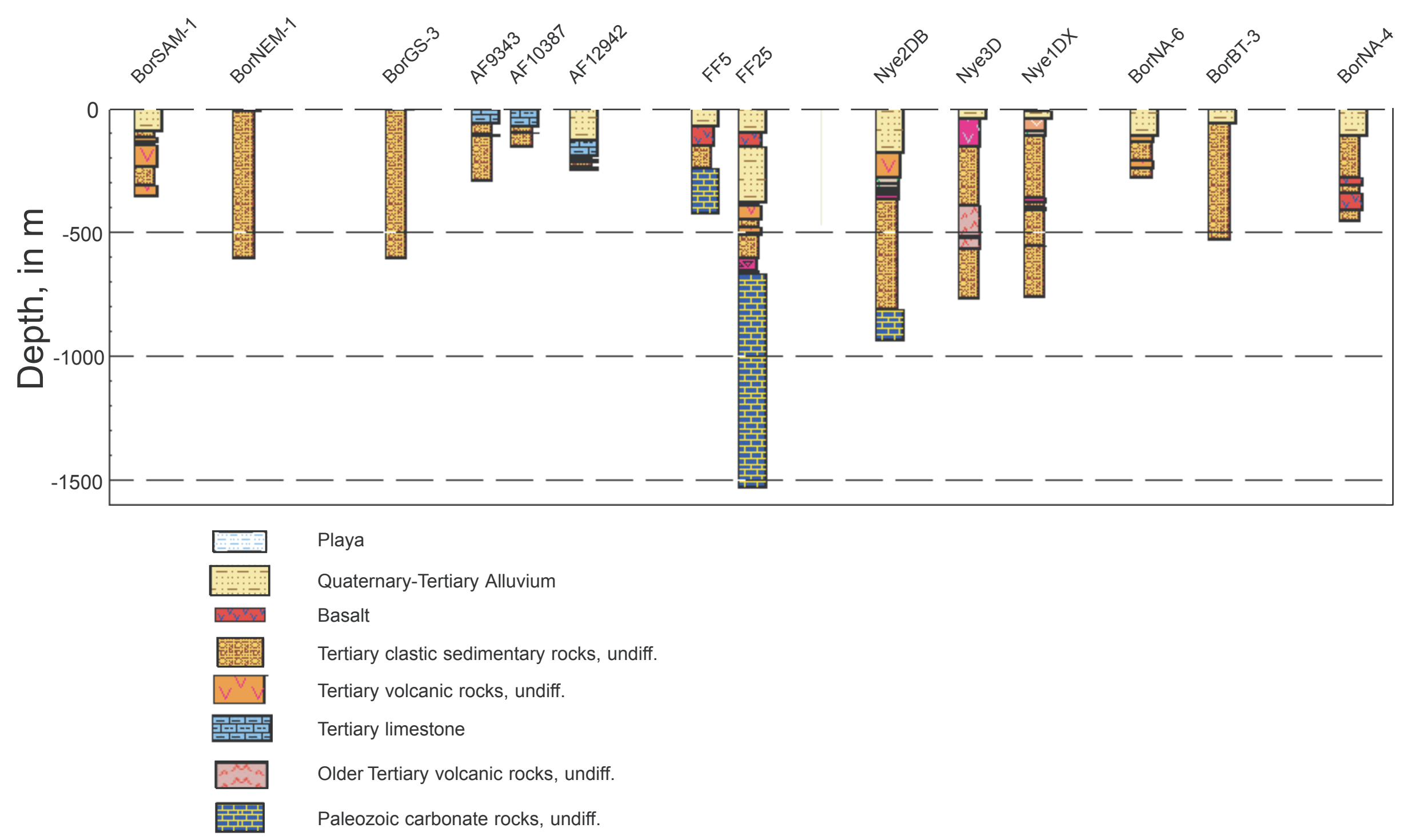

Figure 13. Stratigraphic cross section B-B'. Section is oriented approximately north-south along the axis of the Amargosa Desert. See fig. 11 for section line. 


\section{Summary of Material Properties}

On the basis of the distribution of sedimentary and volcanic components and structural setting of the Tertiary basin-filling rocks of the Death Valley ground-water basin, five broad zones have been delineated (fig. 14) that represent areas with potentially distinct material properties and potentially different hydraulic properties. Each of these zones is discussed below.

Zone 1: This zone includes the eastern part of region. Stratigraphic successions consist of early extensional to synextensional sediments that are largely free of volcanic rocks and occupy regions that have been moderately extended. This region includes the Las Vegas Valley, the Indian Springs area and valleys to the north of Indian Springs and the southeastern portion of the Nevada Test Site. The Pahrump Valley is shown as a sub region. Tertiary strata in this basin are not as well characterized, but the basin is far enough away from volcanic fields that the sedimentary successions are likely to be similar to those elsewhere in this zone.

Zone 2: This zone corresponds to marginal parts of the southwestern Nevada volcanic field, where Tertiary sedimentary rocks underlie a thick sequence of regionally extensive ash-flow tuffs. Volcanic rocks penetrated by boreholes may not have been explicitly identified, but are probably derived from the southwestern Nevada volcanic field.

Zone 3: This zone includes synextensional sediments related to extreme extension. Coarse synextensional gravels and megabreccias characterize these sections. Included in this region are the Shadow Valley supradetachment basin, Death Valley, and the Nova basin to the west of Death Valley.

Zone 4: This zone includes the synextensional volcano-sedimentary trough that incorporates the central Death Valley volcanic-plutonic field and the Furnace Creek basin. Stratigraphic successions are a mixed assemblage of sedimentary and volcanic rocks whose deposition was closely associated with movement along the Furnace Creek fault zone. 


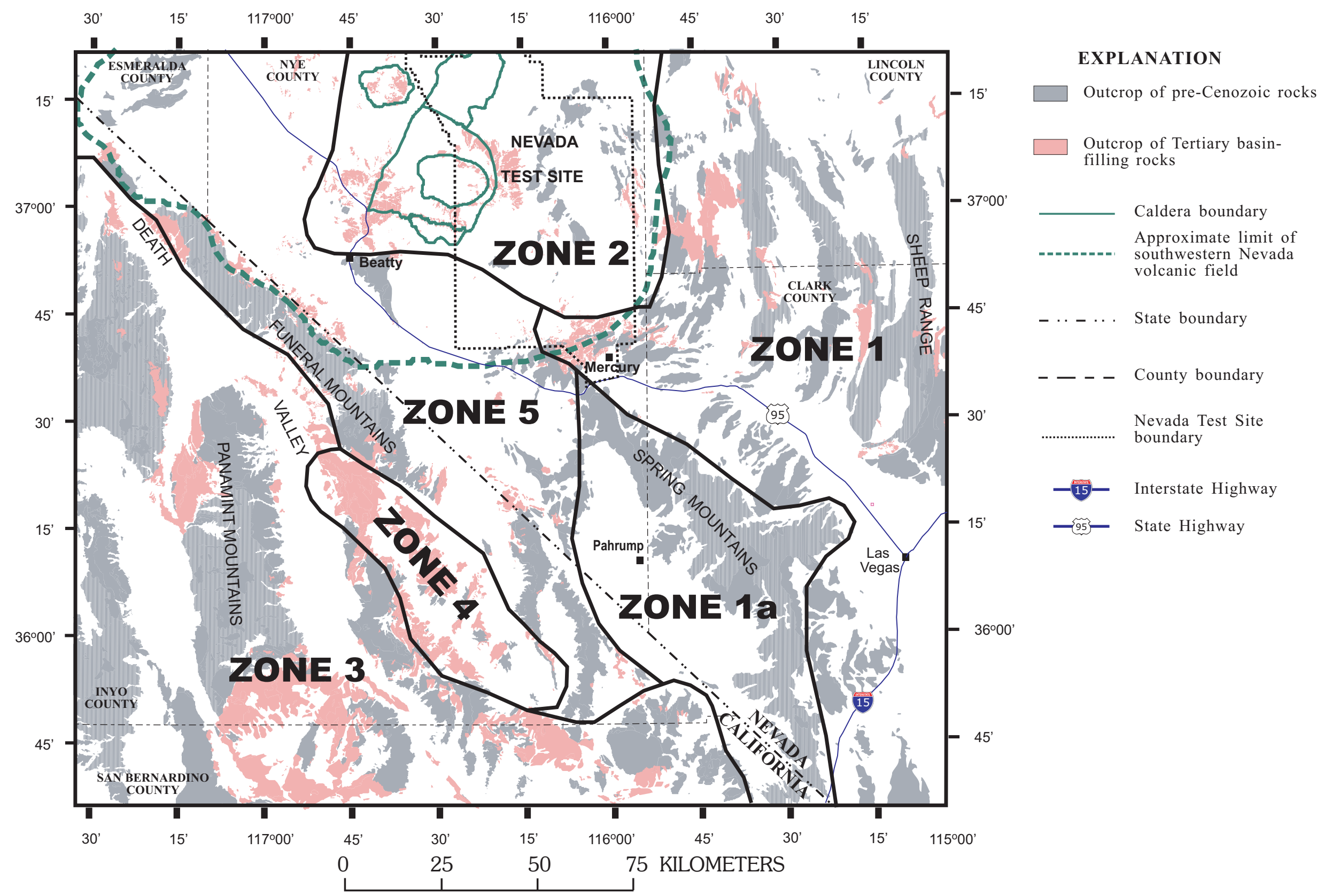

Figure 14. Map showing location of zones that may define major regional differences in material properties. 
Zone 5: Stratigraphic successions within this zone are similar only in their generally high stratigraphic and structural complexity. The region is characterized by its wide variety of sedimentary rocks, including coarse-and fine-grained alluvial fill, lacustrine deposits and playa deposits, fluvially reworked tuffs and tuffaceous sedimentary rocks that span an age range from Oligocene to the Pliocene. Volcanic rocks are present in varying proportions. These rocks have been affected both by extension and by strike-slip deformation associated with the Stewart Valley-Pahrump fault zone.

The sum effect of all of the above is that a few of the basin fills are fairly permeable top to bottom and a few are impermeable top to bottom. But most of the basin fills could either be represented by an aquifer overlying a leaky confining unit, or alternatively, by a single unit that decreases in permeability with depth. 


\section{References Cited}

Barnes, Harley, Ekren, E.B., Rogers, C.L., and Hedlund, D.C., 1982, Geologic and tectonic maps of the Mercury quadrangle, Nye and Clark Counties, Nevada: U.S. Geological Survey Miscellaneous Investigations Map I-1197, 1 sheet, scale 1:24,000.

Bedinger, M.S., Langer, W.H., and Reed, J.E., 1989, Ground-water hydrology, in Bedinger, M.S., Sargent, K.A., and Langer, W.H., eds., Studies of geology and hydrology in the Basin and Range Province, Southwestern United States, for isolation of high-level radioactive waste-Characterization of the Death Valley region, Nevada and California: U.S. Geological Survey Professional Paper 1370-F, p. 28-35.

Blakely, R.J., Jachens, R.C., Calzia, J.P., and Langenheim, V.E., 1999, Cenozoic basins of the Death Valley extended terrane as reflected in regional gravity anomalies, in Wright. L.A., and Troxel, B.W., eds., Cenozoic Basins of the Death Valley Region: Geological Society of America Special Paper 333, p. 1-16, Boulder, Colorado.

Blakely, R.J., Langenheim, V.E., Ponce, D.A., and Dixon, G.L., 2000, Aeromagnetic Survey of the Amargosa Desert, Nevada and California - A Tool for Understanding Near-Surface Geology and Hydrology: U.S. Geological Survey Open-File Report 00-188, 39 p., 2 plates.

Blakely, R.J., Morin, R.L., McKee, E.H., Schmidt, K.M., Langenheim, V.E., and Dixon, G.L., 1998, Threedimensional model of pre-Cenozoic basement beneath Amargosa Desert and Pahrump Valley, California and Nevada - Implications for tectonic evolution and water resources: U.S. Geological Survey Open-File-Report 98-496, 29 p.

Blankennagel, R.K., and Weir, J.E., Jr., 1973, Geohydrology of the eastern part of Pahute Mesa, Nevada Test Site, Nye County, Nevada: U.S. Geological Survey Professional Paper 712-B, 35 p.

Bohannon, R.G., 1984, Nonmarine sedimentary rocks of Tertiary age in the Lake Mead Region, southeastern Nevada and northwestern Arizona: USGS Professional Paper 1259, 72 p., 1 plate.

Byers, F.M. Jr., Carr, W.J., Orkild, P.P., Quinlivan, W.D., and Sargent, K.A., 1976, Volcanic suites and related cauldrons of the Timber Mountain-Oasis Valley caldera complex, southern Nevada: U.S. Geological Survey Professional Paper 919, 70 p.

Carr, W.J., Keller, S.M., and Grow, J.A., 1995, Lithologic and geophysical logs of drill holes Felderhoff Federal 5-1 and 25-1, Amargosa Desert, Nye County, Nevada: U.S. Geological Survey Open-File Report 95-155, $14 \mathrm{p}$.

Cemen, Ibrahim, 1983, Stratigraphy, geochronology and structure of the selected areas of the northern Death Valley region, eastern California-western Nevada, and implications concerning Cenozoic tectonics of the region: University Park, Penn., Pennsylvania State University Ph.D. thesis, 235 p, 1 map, scale 1:12,000.

Cemen, Ibrahim, 1999, Tectonostratigraphic relationship between the Cenozoic sedimentary successions of the southern Funeral Mountains, Furnace Creek basin, Eagle Mountain, and the north end of the Resting Spring range, in Slate, J.L., ed., Proceedings of conference on status of geologic research and mapping in Death Valley National Park, Las Vegas, Nevada, April, 9-11, 1999: U.S. Geological Survey Open-File Report 99-153, p. 56-57. 
Cemen, Ibrahim, Wright, L.A., Drake, R.E. and Johnson, F.C., 1985, Cenozoic sedimentation and sequence of deformational events at the southeastern end of the Furnace Creek strike-slip fault zone, Death Valley region, California, in Biddle, K.T. and Christie-Blick, Nicholas, eds., Strike-slip deformation and basin formation: Society of Economic Paleontologists and Mineralogists Special Publication 37, p. 127-141.

Cemen, Ibrahim, Wright, L.A., and Prave, A.R., 1999, Stratigraphy, and tectonic implications of the latest Oligocene and early Miocene sedimentary succession, southernmost Funeral Mountains, Death Valley region, California, in Cenozoic basins of the Death Valley region: Wright, L.A. and Troxel, B.W., eds., Geological Society of America Special Paper 333, p. 65-86.

Chesterman, C.W., 1973, Geology of the northeast quarter of Shoshone quadrangle, Inyo County, California: California Division of Mines and Geology Map Sheet 18, 1 sheet, scale1:24,000.

D'Agnese, F.A., Faunt, C.C., Turner, A.K., and Hill, M.C., 1997, Hydrogeologic evaluation and numerical simulation of the Death Valley regional ground-water system, Nevada and California: U.S. Geological Survey Water-Resources Investigation Report 96-4300, 124 p.

Denny, C.S., and Drewes, Harald, 1965, Geology of the Ash Meadows Quadrangle, Nevada-California the history of a desert basin and its bordering highlands: U.S. Geological Survey Bulletin 1181-L, 56 p., 1 plate, scale 1:62,500.

Dudley, W.W., Jr., and Larson, J.D., 1976, Effect of irrigation pumping on desert pupfish habitats in Ash Meadows, Nye County, Nevada: U.S. Geological Survey Professional Paper 927, 52 p.

Drewes, Harald, 1963, Geology of the Funeral Peak quadrangle, California, on the east flank of Death Valley: U.S. Geological Survey Professional Paper 413, 78 p., 2 plates, scale 1:62,500.

Ekren, E.B., Orkild, P.P., Sargent, K.A., and Dixon, G.L., 1977, Geologic map of Tertiary rocks, Lincoln County, Nevada: U.S. Geological Survey Miscellaneous Investigations Series Map I-1041, scale $1: 250,000$.

Fowler, T.K., Jr., and Calzia, J.P., 1999, Kingston Range detachment fault, southeastern Death Valley region, California - relation to Tertiary deposits and reconstruction of initial dip, in Wright, L.A., and Troxel, B. W., eds., Cenozoic basins of the Death Valley region: Geological Society of America Special Paper 333, p. 245-257.

Friedmann, S.J., 1999, Sedimentology and stratigraphy of the Shadow Valley basin, eastern Mojave Desert, California, in Cenozoic basins of the Death Valley region: Wright, L.A. and Troxel, B.W., eds., Geological Society of America Special Paper 333, p. 213-244.

Fridrich, C.J., 1999, Tectonic evolution of the Crater Flat basin, Yucca Mountain region, Nevada, in Wright, L.A., and Troxel, B.W., eds., Cenozoic basins of the Death Valley region: Geological Society of America Special Paper 333, p.169-195.

Fridrich, C.J., Dudley Jr., W.W., and Stuckless, J.S., 1994, Hydrogeologic analysis of the saturated-zone ground-water system, under Yucca Mountain, Nevada: Journal of Hydrology, v. 154, p. 133-168.

Fridrich, C.J., Minor, S.A., and Mankinen, E.A., 1999, Geologic evaluation of the Oasis Valley basin, Nye County, Nevada: U.S. Geological Survey Open-File Report 99-0533-A, 55 p. 
Fridrich, C.J., Minor, S.A., Ryder, P.L., and Slate, J.L., with contributions form Warren, R.G., Hildenbrand, T.G., Sawyer, D.A., and Orkild, P.P., 1999, Geologic map of the Oasis Valley Basin and vicinity, Nye County, Nevada: U.S. Geological Survey Open-File Report 99-533-B, scale 1:62,500.

Fridrich, C.J., Thompson, R.A., Machette, M.N., and Miggins, D.P., 2000, Late Cenozoic stratigraphic record of tectonic evolution, volcanism, and climate change in the Death Valley region, California and Nevada: EOS, Transactions, American Geophysical Union, v. 81, p. F1127.

Fridrich, C.J., Whitney, J.W., Hudson, M.R., and Crowe, B.M., 1999, Space-time patterns of Late Cenozoic extension, vertical-axis rotation, and volcanism in the Crater Flat basin, southwest Nevada, in Wright, L.A., and Troxel, B.W., eds., Cenozoic basins of the Death Valley region: Geological Society of America Special Paper 333, p. 197-212.

Grauch, V.J.S., Sawyer, D.A., Fridrich, C.J., and Hudson, M.R., 1999, Geophysical framework of the southwestern Nevada volcanic field and hydrogeologic implications: U.S. Geological Survey Professional Paper 1608, $39 \mathrm{p}$.

Greene, R.C., 1997, Geology of the northern Black Mountains, Death Valley, California: U.S. Geological Survey Open-File Report 97-79, 82 p., 3 plates, scale 1:24,000.

Guth, P.L., Schmidt, D.L., Deibert, Jack, and Yount, J.C., 1988, Tertiary extensional basins of northwestern Clark County, Nevada, in Weide, D.L., and Faber, M.L., eds., This Extended Land Geological journeys in the southern Basin and Range: Geological Society of America Cordilleran Section Field Trip Guidebook, p. 239-254.

Harrill, J.R., 1986, Ground-water storage depletion in Pahrump Valley, Nevada-California, 1962-75: U.S. Geological Survey Water-Supply Paper 2279, 52 p., 3 plates.

Hinrichs, E.N., 1968, Geologic map of the Camp Desert Rock quadrangle, Nye County, Nevada: U.S. Geological Survey Geologic Quadrangle Map GQ-726, scale 1:24,000.

Hinrichs, E.N. and McKay, E.J., 1965, Geologic map of the Plutonium Valley quadrangle, Nye and Lincoln Counties, Nevada: U.S. Geological Survey Geologic Quadrangle Map G0-384, scale 1:24,000.

Hodges, K.V., McKenna, L.W., Stock, J., Knapp, J., Page, L., Sternlof, K., Silverberg, D., Wust, G., and Walker, J.D., 1989, Evolution of extensional basins and Basin and Range topography west of Death Valley, California: Tectonics, v. 8, p. 453-467, 1 plate.

Holm, D.K., Pavlis, T.L., and Topping, D.J., 1994, Black Mountains crustal section, Death Valley extended terrane, California, in McGill, S.F., and Ross, T.M., eds., Geological investigations of an active margin: Geological Society of America Cordilleran Section Fieldtrip Guidebook, Trip 2, San Bernardino, California, p. 31-54.

Hunt, C.B., Robinson, T.W., Bowles, W.A., and Washburn, A.L., 1966, Hydrologic basin, Death Valley, California: U.S. Geological Survey Professional Paper 494-B, 138 p., with 3 plates.

IT Corporation, 1996, Underground Test Area Subproject Phase I Data Analysis Task (Vol. I)-Regional geologic model data documentation package: ITLV/10972-81, 407 p.

Jachens, R.C., and Moring, D.R., 1990, Maps of thickness of Cenozoic deposits and the isostatic residual gravity over basement for Nevada: U.S. Geological Survey Open-File Report 90-404, scale $1: 1,000,000$. 
Johnston, R.H., 1968, U.S. Geological Survey tracer study, Amargosa Desert, Nye County, Nevada-Part I, Exploratory drilling, tracer well construction and testing, and preliminary findings: U.S. Geological Survey Open-File Report 474-098, 64 p.

Laczniak, R.J., Cole, J.C., Sawyer, D.A., and Trudeau, D.A., 1996, Summary of hydrogeologic controls on ground-water flow at the Nevada Test Site, Nye County, Nevada: U.S. Geological Survey WaterResources Investigations Report 96-4109, 59 p.

Longwell, C.R., Pampeyan, E.H., Bowyer, Ben, and Roberts, R.J., 1965, Geology and mineral deposits of Clark County, Nevada: Nevada Bureau of Mines and Geology Bulletin 62, 218 p.

Luckey, R.R., Tucci, Patrick, Faunt, C.C., Ervin, E.M., Steinkampf, W.C., D'Agnese, F.A., and Patterson, G.L., 1996, Status of understanding of the saturated-zone ground-water flow system at Yucca Mountain, Nevada as of 1995: U.S. Geological Survey Water-Resources Investigations Report 964077, $71 \mathrm{p}$.

Maldonado, Florian, 1990, Structural geology of the upper plate of the Bullfrog Hills detachment fault system, southern Nevada: Geological Society of America Bulletin, v. 102, p. 992-1006.

McAllister, J.F., 1970, Geology of the Furnace Creek borate area, Death Valley, Inyo County, California: California Department of Conservation, Division of Mines and Geology Map Sheet 14, scale $1: 24,000$, with accompanying text.

McAllister, J.F., 1973, Geologic map and sections of the Amargosa Valley borate area-Southeast continuation of the Furnace Creek area, Inyo County, California: U.S. Geological Survey Miscellaneous Geologic Investigations Map 1-782, 1 sheet, scale 1:24,000.

McAllister, J.F., 1974, Geologic maps and sections of a strip from Pyramid Peak to the southeast end of the Funeral Mountains, Ryan Quadrangle, California, in Guidebook-Death Valley Region, California and Nevada: Shoshone, Calif., The Death Valley Publishing Company, p. 81-83.

McKenna, L.W. and Hodges, K.V., 1990, Constraints on the kinematics and timing of late Miocene-Recent extension between the Panamint and Black Mountains, southeastern California, in Wernicke, B.P., ed., Basin and Range extensional tectonics near the latitude of Las Vegas, Nevada: Geological Society of America Memoir 176, p. 363-376, map scale 1:5,840.

Monsen, S.A., Carr, M.D., Reheis, M.C., and Orkild, P.P., 1992, Geologic map of Bare Mountain, Nye County, Nevada; U.S. Geological Survey Miscellaneous Investigations Series Map I-2201, scale $1: 24,000$.

Morrison, R.B., 1999, Lake Tecopa - Quaternary geology of Tecopa Valley, California, a multimillion-year record and its relevance to the proposed nuclear-waste repository at Yucca Mountain, Nevada: in Wright. L.A., and Troxel, B.W., eds., Cenozoic Basins of the Death Valley Region: Geological Society of America Special Paper 333, p. 301-344.

Naff, R.L., 1973, Hydrogeology of the southern part of Amargosa Desert in Nevada: Reno, Nev., University of Nevada at Reno M.S. thesis, 207 p.

Niemi, N.A., Wernicke B.P., Brady R.J., and Saleeby J.B., 2001, Distribution and provenance of the middle Miocene Eagle Mountain Formation, and implications for regional kinematic analysis of the Basin and Range province: Geological Society of America Bulletin, v. 113, p. 419-442. 
Oatfield, W.J., and Czarnecki, J.B., 1989, Hydrogeologic inferences from driller's logs and from gravity and resistivity surveys in the Amargosa Desert, southern Nevada: U.S. Geological Survey Open-File Report 89-234, $296 \mathrm{p}$.

Plume, R.W., 1989, Ground-water conditions in Las Vegas valley, Clark County, Nevada-Part 1, Hydrogeologic framework: U.S. Geological Survey Water-Supply Paper 2320-A, 15 p, 5 plates.

Prave, A.R., and McMackin, M.R., 1999, Depositional framework of mid to Late Miocene strata in the Dumont Hills and along the margin of the Kingston Range: Tentative implications for the tectonostratigraphic evolution of the southern Death Valley region, in Wright, L.A., and Troxel, B. W., eds., Cenozoic basins of the Death Valley region: Geological Society of America Special Paper 333, p. $259-288$.

Reynolds, M.W., 1974, Geology of the Grapevine Mountains, Death Valley, California-A summary, in Guidebook-Death Valley Region, California and Nevada: Shoshone, Calif., The Death Valley Publishing Company, p. 92-99.

Saltus, R.W., and Jachens, R.C., 1995, Gravity and basin-depth maps of the Basin and Range Province, western United States: U.S. Geological Survey Geophysical Investigations Map 1012, scale $1: 250,000$.

Sawyer, D.A., Fleck, R.J., Lanphere, M.A., Warren, R.G., Broxton, D.E., and Hudson, M.R., 1994, Episodic caldera volcanism in the Miocene southwestern Nevada volcanic field: revised stratigraphic framework, ${ }^{40} \mathrm{Ar} /{ }^{39} \mathrm{Ar}$ geochronology, and implications for magmatism and extension: Geological Society of America Bulletin, v. 106, p.1304-1318.

Snow, J.K., and Lux, D.R., 1999, Tectono-sequence stratigraphy of Tertiary rocks in the Cottonwood Mountains and northern Death Valley area, in Wright, L.A., and Troxel, B.W., eds., Cenozoic basins of the Death Valley region: Geological Society of America Special Paper 333, p. 17-64.

Topping, D.J., 1993, Paleogeographic reconstruction of the Death Valley extended region, evidence from Miocene large rock-avalanche deposits in the Amargosa Chaos Basin, California: Geological Society of America Bulletin, v. 105, p. 1190-1213.

Tschanz, C.M., and Pampeyan, E.H., 1970, Geology and Mineral deposits of Lincoln County, Nevada: Nevada Bureau of Mines and Geology Bulletin 73, $188 \mathrm{p}$.

Waddell, R.K., Robison, J.H., and Blankennagel, R.K., 1984, Hydrology of Yucca Mountain and vicinity, Nevada- California-Investigative results through mid-1983: U.S. Geological Survey WaterResources Investigations Report 84-4267, 72 p.

Winograd, I.J., and Thordarson, William, 1975, Hydrogeologic and hydrochemical framework, southcentral Great Basin, Nevada-California, with special reference to the Nevada Test Site: U.S. Geological Survey Professional Paper 712-C, $126 \mathrm{p}$.

Wright, L.A., 1989, Overview of the role of strike-slip and normal faulting in the Neogene history of the region northeast of Death Valley, California-Nevada, in Ellis,M.A., ed., Late Cenozoic evolution of the southern Great Basin: Nevada Bureau of Mines and Geology Open-File Report 89-1, p. 1-11.

Wright. L.A., 1999, Cenozoic basins of the central Death Valley region, eastern California, in Slate, J.L., ed., Proceedings of Conference on status of geologic research and mapping in Death Valley National 
Park, Las Vegas, Nevada, April, 9-11, 1999: U.S. Geological Survey Open-File Report 99-153, p. 41 46.

Wright, L.A., and Troxel, B.W., 1984, Geology of the northern half of the Confidence Hills 15-minute quadrangle, Death Valley region, eastern California - the area of the Amargosa Chaos: California Department of Conservation, Division of Mines and Geology Map Sheet 34, 31 p, scale 1:24,000.

Wright, L.A., and Troxel, B.W., 1993, Geologic map of the central and northern Funeral Mountains and adjacent areas, Death Valley region, southern California: U.S. Geological Survey Miscellaneous Investigations Map I-2305, scale 1:48,000.

Wright, L.A., Greene, R.C., Cemen, Ibrahim, Johnson, F.C., and Prave, A.R., 1999, Tectonostratigraphic development of the Miocene-Pliocene Furnace Creek Basin and related features, Death Valley region, California: in Wright. L.A., and Troxel, B.W., eds., Cenozoic Basins of the Death Valley Region: Geological Society of America Special Paper 333, p. 87-114.

Wright, L.A., Thompson, R.A., Troxel, B.W., Pavlis, T.L., DeWitt, E., Otton, J.K., Ellis, M.A., Miller, M.G., and Serpa, L.F., 1991, Cenozoic magmatic and tectonic evolution of the east-central Death Valley region, California, in Walawender, M.J., and Hanan, B.B., eds., Geological excursions in southern California and Mexico: Geological Society of America, Geological Society of America Annual Meeting Guidebook 1991, p. 93-127.

Wright, L.A., Troxel, B.W., Burchfiel, B.C., Chapman, R.H., and Labotka, T.C., 1981, Geologic cross section from the Sierra Nevada to the Las Vegas Valley, eastern California to southern Nevada: Geological Society of America Map and Chart Series, MC-28M, p. 3-15, 1 plate. 